\title{
SOEP
}

SOEPpapers

on Multidisciplinary Panel Data Research

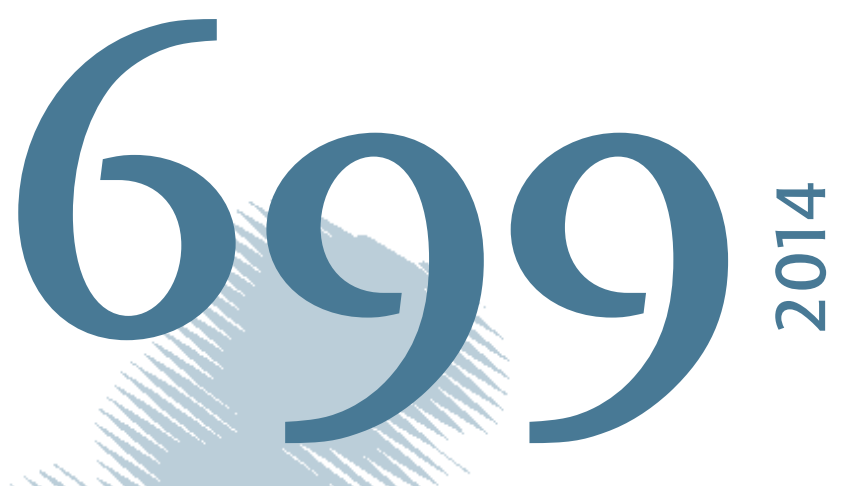

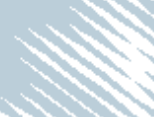

\section{On the Misery of Losing Self-employment}




\section{SOEPpapers on Multidisciplinary Panel Data Research}

at DIW Berlin

This series presents research findings based either directly on data from the German SocioEconomic Panel Study (SOEP) or using SOEP data as part of an internationally comparable data set (e.g. CNEF, ECHP, LIS, LWS, CHER/PACO). SOEP is a truly multidisciplinary household panel study covering a wide range of social and behavioral sciences: economics, sociology, psychology, survey methodology, econometrics and applied statistics, educational science, political science, public health, behavioral genetics, demography, geography, and sport science.

The decision to publish a submission in SOEPpapers is made by a board of editors chosen by the DIW Berlin to represent the wide range of disciplines covered by SOEP. There is no external referee process and papers are either accepted or rejected without revision. Papers appear in this series as works in progress and may also appear elsewhere. They often represent preliminary studies and are circulated to encourage discussion. Citation of such a paper should account for its provisional character. A revised version may be requested from the author directly.

Any opinions expressed in this series are those of the author(s) and not those of DIW Berlin. Research disseminated by DIW Berlin may include views on public policy issues, but the institute itself takes no institutional policy positions.

The SOEPpapers are available at

http://www.diw.de/soeppapers

\section{Editors:}

Jürgen Schupp (Sociology)

Gert G. Wagner (Social Sciences, Vice Dean DIW Graduate Center)

Conchita D'Ambrosio (Public Economics)

Denis Gerstorf (Psychology, DIW Research Director)

Elke Holst (Gender Studies, DIW Research Director)

Frauke Kreuter (Survey Methodology, DIW Research Professor)

Martin Kroh (Political Science and Survey Methodology)

Frieder R. Lang (Psychology, DIW Research Professor)

Henning Lohmann (Sociology, DIW Research Professor)

Jörg-Peter Schräpler (Survey Methodology, DIW Research Professor)

Thomas Siedler (Empirical Economics)

C. Katharina Spieß (Empirical Economics and Educational Science)

ISSN: 1864-6689 (online)

German Socio-Economic Panel Study (SOEP)

DIW Berlin

Mohrenstrasse 58

10117 Berlin, Germany

Contact: Uta Rahmann | soeppapers@diw.de 


\title{
On the Misery of Losing Self-employment
}

\author{
Clemens Hetschko*
}

Freie Universität Berlin

\section{October 2014}

\section{Abstract}

German Socio-Economic Panel data is used to show that the decrease in life satisfaction caused by an increase in the probability of losing work is higher when self-employed than when paid employed. Further estimations reveal that becoming unemployed reduces selfemployed workers' satisfaction considerably more than salaried workers' satisfaction. These results indicate that losing self-employment is an even more harmful life event than losing dependent employment. Monetary and non-monetary reasons seem to account for the difference between the two types of work. Moreover, it originates from the process of losing self-employment and the consequences of unemployment rather than from advantages of selfemployment.

JEL Classification: I31; J24; J65; L26

Keywords: life satisfaction; self-employment; probability of losing work; unemployment; SOEP

\footnotetext{
Acknowledgements: The author is very grateful to Ronnie Schöb, Andreas Knabe, Adrian Chadi, Katja Görlitz, Laszlo Goerke, Malte Preuß and Silva Lea Haselon as well as to participants of the Quality of Life Conference (Berlin 2014), the HEIRs Conference on Public Happiness (Rome 2013) and the Workshop in Economics (Trier 2013).

* Freie Universität Berlin, School of Business and Economics, Boltzmannstraße 20, D-14195 Berlin, Clemens.Hetschko@fu-berlin.de.
} 


\section{Introduction}

Successful entrepreneurs increase economic growth and create jobs. They contribute to innovation, knowledge diffusion and market efficiency. These possibilities may play a part in motivating policies that incentivise workers to become self-employed despite the fact that a lot of start-ups do not succeed. ${ }^{1}$ Encouraging 'the right' people to start a business requires an understanding of the reasons that affect a worker's choice between self-employment and dependent employment. ${ }^{2}$ The risks of self-employment have consistently been considered in this context. Recent empirical evidence based on large panel data indeed confirms that the more risk-averse people are, the less likely they go into business (Caliendo et al. 2009, 2014). In consequence, higher risks for self-employed workers than for salaried workers can explain why people hesitate to become self-employed. This study considers the utility effect of losing work as such a risk. Following research that measures the individual welfare cost of unemployment (e.g. Clark and Oswald 1994), this potential risk is assessed using well-being data. The aim here is, first and foremost, to answer two questions: Does losing selfemployment lead to a stronger reduction of life satisfaction than losing dependent employment? Do people anticipate such a difference when they are self-employed or paid employed?

The self-employed enjoy several pleasant work characteristics that increase their job satisfaction on average above the level of salaried workers (e.g. Benz and Frey 2008a). If this difference translates into higher general well-being, the transition from self-employment to unemployment is accompanied by a stronger decline in life satisfaction than the transition from dependent employment to unemployment because the former fall from a higher level than the latter. However, the level of well-being after losing work might differ as well. Lost self-employment may be more strongly associated with a feeling of personal failure and a deviation from one's ideal self because running the firm contributes more to it functioning successfully than working for it. In contrast, if the former self-employed are more likely to find a new job soon, they might be better-off since promising future employment prospects increase the well-being of the unemployed (Knabe and Rätzel 2010). It is also conceivable

\footnotetext{
${ }^{1}$ See European Commission (2010) for several examples of policy measures aimed at supporting start-ups as well as Shane (2008) for a critical discussion.

${ }^{2}$ See Parker (2009) for an extensive account of theoretical and empirical work that has been done on this issue.
} 
that employers suffer from the necessity of having to dismiss employees when their firm fails (Torres 2011).

The individual monetary consequences of business failure are likely to be different from those of losing a paid job as well. Self-employed workers may run into debt more often and are less likely to receive benefits out of public unemployment insurance than salaried workers (Schulze Buschoff 2007). Thus, both the current financial situation as well as future income prospects might differ between the two groups. If being needy goes along with deviating from the social norm of making one's own living, a higher prevalence of welfare recipients among workers who lost self-employment compared to workers who lost dependent employment might explain why the former suffer more than the latter (see e.g., Chadi 2012).

It has so far remained unexplored whether these or other reasons lead to a difference in the individual welfare cost of unemployment between self-employment and dependent employment. The present study fills this gap by analysing the potential well-being effect of losing self-employment using life satisfaction data of the German Socio-Economic Panel study (SOEP) and comparing it to that of losing dependent employment. A first identification strategy analyses the anticipation of the loss of work when workers are either self-employed or paid employed. The results of multiple regressions suggest that a growing expectation of loss of work within the next two years lowers life satisfaction much more when self-employed than when paid employed. Thus, the loss of self-employment seems to be an even more harmful life event than the loss of dependent employment. This interpretation is strengthened further by the results from a second identification strategy which does not rely on the same assumptions as the first approach. Comparing the reasons for entry into unemployment, it is found that workers who give up self-employment experience a much larger decline in life satisfaction than those who lose their jobs due to plant closures, are dismissed, resign or reach the end of their work contract.

The two identification strategies make it possible to shed some light on the potential reasons why the self-employed seem to suffer more from losing work than salaried workers do. It turns out that lower satisfaction of the former self-employed after entering unemployment, rather than a higher satisfaction level beforehand, explains this difference. Hence, the consequences of losing work drive apart the different declines in life satisfaction. Furthermore, both monetary and non-monetary factors seem to explain the difference in the individual welfare cost of unemployment between the two types of work. 
The present study links and complements three major directions of economic research on subjective well-being. First, it adds to analyses of the well-being effect of unemployment by discovering that being self-employed prior to unemployment boosts this individual welfare cost, which has not been documented so far. Similarly, the present investigation extends, second, insights about the relationship of future employment prospects and current subjective well-being by revealing that self-employed workers suffer more from expecting the loss of work than salaried workers do. Third, the study complements research investigating the general difference in well-being between self-employment and dependent employment by indicating that the current probability of losing work determines whether the one or the other type of work is more promising. Self-employment appears to be at least of equal value to dependent employment as long as the probability of losing work is relatively low. But when work is at very high risk of being lost, or even lost, self-employment reduces life satisfaction more than dependent employment.

In the following, Section 2 summarises major results of these three areas of research. The empirical identification strategies are described in Section 3. Section 4 documents data and sampling. Section 5 and Section 6 present results obtained from applying the two identification strategies. Section 7 concludes.

\section{Previous literature}

The present study is related to previous literature analysing the well-being effects of unemployment and insecurity of work. This research shows clearly that losing one's job causes a huge reduction in life satisfaction that cannot be explained by the reduction in income alone (e.g. Clark and Oswald 1994, Winkelmann and Winkelmann 1998, Di Tella et al. 2001, Blanchflower and Oswald 2004, Kassenboehmer and Haisken-De New 2009). In fact, non-pecuniary consequences of losing work, such as being unable to match one's ideal self due to deviating from norms of working, matter as well (e.g. Clark 2003; Stutzer and Lalive 2004; Van Hoorn and Maseland 2013; Hetschko, Knabe and Schöb 2014). Monetary and non-monetary reasons may also explain why workers who remain unemployed for a long time do not get used to this status. Their life satisfaction does not recover as time goes by, in contrast to life satisfaction after many other severe life events (e.g. Clark et al. 2008a) and despite the fact that some measures of emotional well-being recover, if they fall at all (Knabe et al. 2010, Krueger and Mueller 2012). 
Part of the negative impact of an unemployment spell on life satisfaction seems to persist like a scar even when workers are reemployed (Clark et al. 2001). One reason may be that unemployment in the past increases the risk of future unemployment and, hence, reduces well-being (Knabe and Rätzel 2011). In general, increasing uncertainty about future employment stability reduces well-being substantially, regardless of whether such insecurity is induced by others' unemployment (e.g. Clark et al. 2010, Luechinger et al. 2010), one's own perceptions of job insecurity and employability (e.g. Knabe and Rätzel 2010, Green 2011) or 'objective insecurity' as in the case of fixed-term employment (Chadi and Hetschko 2013).

Although the average impact of unemployment on overall well-being is clearly negative, the effect varies substantially between workers (Gielen and van Ours 2014). Hence, the circumstances of losing work as well as individual characteristics may modify the misery of unemployment. In this respect, it has been shown that men suffer more than women (e.g. Gerlach and Stephan 1996), whereas social capital in terms of social networks and social activities does not seem to play a role (Winkelmann 2009). A further potential explanation for the variation in individual reactions of well-being to unemployment is the type of work prior to unemployment (either self-employment or dependent employment). However, this aspect has been neglected so far. The question of why some people suffer from losing work more than others is a part of understanding the impact of unemployment. Policies which aim at supporting or activating unemployed workers need to take into consideration the personal characteristics that modify the welfare cost of unemployment in order to identify target groups for different labour market policies. Therefore, in contrast to previous studies, the role of prior self-employment in the well-being effect of losing work is analysed in this study.

A few studies compare perceptions of the security of current work between dependent employment and self-employment, albeit without linking them to life satisfaction. Selfemployment is associated with lower security measured as 'satisfaction with job security' than dependent employment (Millàn et al. 2013). However, dependent employment leads to lower security as measured by the self-assessed likelihood of job loss than self-employment (Hundley 2001). This seeming contradiction is revisited and reconciled against the background of the findings presented here in the following.

The present study not only complements research on the well-being effects of unemployment and insecurity at work. It also adds to the literature on well-being differences 
between self-employment and dependent employment. A clearly positive view on selfemployment appears in regard to job satisfaction. Running one's own business is a strong source of work-related well-being, offering greater autonomy and more of other pleasant job features than paid employment (e.g. Blanchflower 2000, Hamilton 2000, Parasuranam and Simmers 2001, Benz and Frey 2008a, Benz and Frey 2008b, Lange 2012, Hytti et al. 2013). Self-employment increases, in particular, those workers' job satisfaction who value independence (Fuchs-Schündeln 2009) and who do not have self-employed parents (Clark et al. 2008b).

Andersson (2008) finds that self-employment is positively related to life satisfaction, too, but the results are less robust compared to those of her investigation of job satisfaction. She also reveals that being self-employed is accompanied by more mental health problems, although it seems to be less stressful than being paid-employed. Binder and Coad (2013) summarise the existing evidence on differences in overall well-being between dependent employment and self-employment as sparse and inconclusive. Their own empirical study suggests that this difference depends on contextual factors. It is shown that employment status prior to self-employment is one of them. The transition from dependent employment to selfemployment is more beneficial in regard to life satisfaction than the transition from unemployment to self-employment. A similar relationship applies to entrepreneurs' satisfaction with their start-ups as that is higher for former employed workers than for former unemployed workers (Block and Koellinger 2009). ${ }^{3}$ The present study complements these findings by proposing the use of the current probability of losing work to determine the wellbeing effect of being self-employed. This has been neglected to date.

\section{Identification strategies}

\subsection{An indirect measure: life satisfaction and the probability of losing work}

The first identification strategy employs an indirect approach to comparing the individual welfare cost of losing work between self-employed and paid-employed workers. It is based on three main assumptions. Firstly, the impact of expecting a loss of work in the near future on current subjective well-being may depend on the expected individual welfare cost of this

\footnotetext{
${ }^{3}$ Krause (2013) also focuses on the transition from unemployment to reemployment, but documents another role of life satisfaction: Overall well-being during unemployment is more positively related to being self-employed than to being paid employed in the future.
} 
event (e.g. Geishecker 2012). Growing expectations of losing work affect current life satisfaction all the more, the higher the expected loss in well-being when losing work. Thus, a stronger negative reaction of life satisfaction to an increased probability of losing work when self-employed than when paid employed indicates that self-employment is associated with a higher expected decline in well-being in the event of actual loss of work.

Such a result reflects actual differences in the misery of losing work when a second assumption holds: workers' expectations need to be correct. This implies that people know well how likely they are to lose their work and that such self-reports are unbiased by their current mood. The latter aspect is particularly important for the first identification strategy because current mood might affect self-reports of expectation of loss of work and life satisfaction simultaneously. It may help in this respect that the information used is ascertained with a question that refers to an objective measure, i.e. the probability of losing work (see Section 4 for the exact wording), rather than to a more subjective self-assessment such as concerns about the security of one's job. Regarding the applicability of the second assumption as a whole, the findings of Knabe and Rätzel (2010) as well as Dickerson and Green (2012) suggest that SOEP respondents assess the probability of losing work quite correctly.

The econometric model used to investigate differences in the expected cost of losing work between being self-employed and being paid employed explains the level of life satisfaction $(L S)$ of worker $i$ in year $y$ by type of employment (binary variable for each type, covered by vector $E S$ ) and interactions of type of employment with the current probability of losing work in the near future $(q)$. Based on the two assumptions described above, the difference in the effects of the binary variable for being self-employed times $q$ and the binary variable for being paid employed times $q$ identifies whether life satisfaction when self-employed or when paid employed reacts more strongly to changes in uncertainty about the security of current work. The model also considers socio-demographic characteristics $S D$ and job characteristics $J C$. Time $(\tau)$ and individual fixed-effects $(\varphi)$ are taken into account as well. The constant $\alpha$ measures the average life satisfaction of the reference group; $u$ represents the error term.

$$
L S_{i y}=\alpha+\beta^{\prime} E S_{i y}+\gamma^{\prime}\left(E S_{i y} \cdot q_{i y}\right)+\delta^{\prime} S D_{i y}+\varepsilon^{\prime} J C_{i y}+\tau_{y}+\varphi_{i}+u_{i y}
$$

To interpret the results as effects of combinations of the type of employment and the probability of losing work, one needs to make a third assumption according to which sources of bias such as selection issues do not matter beyond all time-invariant characteristics and further observable characteristics which the model controls for. 


\subsection{A direct measure: life satisfaction and the termination of self-employment}

Two complementary approaches to answering the same question can strengthen interpretations if the results are consistent or raise reasonable doubts if they are not. This consideration motivates a second identification strategy which can be seen as a more direct approach than the first one because it compares the reactions of subjective well-being to the loss of work between self-employed workers and paid-employed workers while the event occurs. The same workers' life satisfaction is compared at two points in time, before the termination of a job ( $t=-1$ in the following) and afterwards $(t=0)$. In so doing, the second approach does not employ information about the current likelihood of losing work and thus obviates the need for the first and the second assumption of the former identification strategy.

The effects of the events are preferably identified by analysing exogenous triggers. Workers who lost their jobs due to plant closures are thus considered the most appropriate comparison group of paid employees (Kassenboehmer and Haisken-De New 2009). In the case of self-employment, it is more difficult to distinguish between voluntary and involuntary terminations. Information about the respondents' employment status in $t=0$ is used to best isolate exogenously triggered terminations of self-employment. Whereas people who give up self-employment and become paid employed or leave the workforce may often switch voluntarily, those who become unemployed are more likely to lose their work involuntarily. The main assumption of the second identification strategy is hence that self-employed people who become unemployed lose work for exogenous reasons. Robustness checks address this issue further (Subsection 6.3). Since the first identification strategy does not rely on the same assumption, it can also be seen as a robustness check at this point.

Some factors might simultaneously explain terminations of employment and changes in well-being. They are controlled for by the following first difference approach. It identifies the difference between self-employed and salaried workers in the changes in life satisfaction between $t=-1$ and $t=0$. The corresponding model (II) explains this change in life satisfaction $\left(\Delta L S=L S_{t=0}-L S_{t=-1}\right)$ by means of a vector of binary variables which represent reasons for the termination of work $(R)$, including the cessation of self-employment, reached end date of a fixed-term contract, dismissal and resignation. The reference category is plant closure. The model also takes into account changes in socio-demographic characteristics (vector $C$ ) as well as levels of socio-demographic characteristics (vector $S D$ ). $\alpha$ denotes the 
average change in life satisfaction of the reference group. $Y$ is a vector of dummies which reflect the years of $t=0 . u_{i}$ is the error term.

$$
\Delta L S_{i}=\alpha+\beta^{\prime} R_{i}+\gamma^{\prime} C_{i}+\delta^{\prime} S D_{i}+\theta^{\prime} Y_{i}+u_{i}
$$

In so doing, it is assumed that potential biases are controlled for by all of the (changes in) characteristics included in the model and by comparing within-person changes.

\section{Data and sampling}

Because of its unique facilities regarding the empirical analyses of this study, data of the German Socio-Economic Panel study (SOEP; see Wagner et al. 2007) is used. The SOEP provides an extraordinarily large set of data, with members of over 10,000 households participating each year. This makes it possible to analyse even such rare life events as becoming unemployed after self-employment. The panel structure makes it possible to compare the same worker's well-being in different employment states. The SOEP contains reliable and consistent information about the individuals' socio-demographic characteristics and many more. The samples analysed in this study consist of people aged between 18 and 65. People are assigned to the employment states self-employed or 'standard' paid employed depending on their self-reported main working activity. They spend at least 15 hours per week doing this work. Observations of unemployment are based on self-reports of this status. 'Nonstandard' paid employees work less than 15 hours and do not report being unemployed. A final group is 'out of the labour force', in that it is neither self-employed, unemployed nor paid employed and reports no working hours. Life satisfaction is used in this study as a proxy for subjective well-being. It is measured by the question

In conclusion, we would like to ask you about your satisfaction with your life in general. Please answer according to the following scale: 0 means 'completely dissatisfied', 10 means 'completely satisfied'. How satisfied are you with your life, all things considered?

As described above, the first identification strategy employs information on the probability of losing work. In line with the recommendation by Dickerson and Green (2012), the corresponding information is obtained from the following question:

How likely is it that you will lose your job within the next two years? Please estimate the probability of such a change according to a scale from 0 to 100.0 means that such a change will definitely not take place. 100 means that such a 
change definitely will take place. All the values in-between can be used for differentiation.

Because of the term 'job', one might wonder whether self-employed workers understand this wording as a request to assess the likelihood of having to give up self-employment. If they believed that this question does not apply to them, they would probably not answer at all or give meaningless answers. However, almost all observations of self-employed workers $(99.6 \%)$ and salaried workers $(99.9 \%)$ contain an answer. Their statements are indeed meaningful which can be seen based on related information: Almost 90\% of self-employed workers who estimate the probability of job loss within the next two years at ' $0 \%$ ' assess the probability of job seeking in the next two years at ' $0 \%$ ' as well. All the answers of selfemployed and salaried workers to these two questions substantially correlate (selfemployment 0.55 , dependent employment 0.47 ). These figures strongly suggest that the selfemployed interpret the question on the probability of job loss as a request to assess the probability of losing self-employment. In the following, the term 'probability of losing work' is used when information from answers to the question on the probability of job loss are employed in order to avoid any confusion.

The question about the probability of losing work is included in six SOEP waves, surveyed in 1999, 2001, 2003, 2005, 2007 and 2009. The first identification strategy is thus based on a panel of biennial observations $(n=56,367)$, which also provides all the other information used here. 4,739 of the observations are of self-employed, 47,613 are of standard paid employed, and 4,015 are of non-standard paid employed. Observations of unemployed workers and people out of the workforce are only included in the sample of the second estimation approach.

The second identification strategy mainly relies on information about triggers of job termination. If such an event occurs between two SOEP interviews, the person is asked "How did that job end?". Five causes are surveyed consistently between 1991 and 1998 as well as from 2001 to 2012: cessation of self-employment, plant closure, end date of fixed-term contract, dismissal and resignation. Observations are compared between the last SOEP interview in the initial job $(t=-1)$ and the first interview afterwards $(t=0)$. The time period between the two is approximately one year. In order to compare similar groups of workers who terminate jobs; at $t=-1$ observations consist of either standard paid employed or selfemployed. At $t=0$, they can be self-employed, paid employed (standard or non-standard) and 
not employed (unemployed or out of labour force). The sample includes 12,605 observations, of which 427 give up self-employment, 1,781 lose their jobs due to plant closures, 1,888 reach the end date of their contracts, 3,694 are dismissed and 4,815 resign. As described in Subsection 2.2, the sample is restricted to observations of unemployment at $t=0$ at a later stage.

Use is also made of SOEP data on disability, overnight stays in hospital during the last twelve months, marital status, children, age, gender, years of unemployment experience, receiving social benefits, years of education, type of self-employment (e.g. freelancer with academic degree), number of employees of self-employed workers, sector, working hours and tenure. Equivalence incomes are calculated based on the modified OECD scale by dividing real household income (at 2006 prices) by the weighted sum of household members (weights are 1 for the first adult, 0.5 for each additional household member that is at least 14 years old, 0.3 for each younger additional household member). Home ownership serves as a proxy of wealth.

\section{Life satisfaction and the probability of losing work}

\subsection{Descriptive insights}

The following mean comparisons provide a first impression of the potential connection of the probability of losing work in the next two years and well-being differences between selfemployment and dependent employment. The probability of losing work ranges between $12 \%$ (standard deviation: 0.21$)$ for self-employed workers, 22\% (0.25) for standard salaried workers and $23 \%(0.27)$ for non-standard salaried workers. The three types of work are broken down into two classes of the probability of losing work $(q)$, one up to $30 \%$ and one above $30 \%$, yielding six groups. The threshold of 30\% denotes the upper quartile of the distribution of the probability in the sample.

Table 1 documents the averages of life satisfaction, socio-demographic characteristics and job characteristics of the six groups. When the probability of losing work is not higher than $30 \%$, self-employment is less promising than standard dependent employment with respect to life satisfaction. ${ }^{4}$ A probability of more than $30 \%$ is associated with lower well-being for all types of work compared to $q \leq 0.3$. The gap between standard salaried workers and self-employed

\footnotetext{
${ }^{4}$ Reported differences in Sections 5 and 6 are statistically significant at least at the $5 \%$ level.
} 
workers in this respect widens substantially. On a very preliminary basis, this indicates that an increased probability of losing work reduces life satisfaction especially when the workers are self-employed.

Table 1: Descriptive statistics - first approach

\begin{tabular}{|c|c|c|c|c|c|c|}
\hline Labour market status & $\begin{array}{l}\text { self- } \\
\text { employed, } \\
q \leq 0.3\end{array}$ & $\begin{array}{l}\text { self- } \\
\text { employed, } \\
q>0.3\end{array}$ & $\begin{array}{l}\text { std. paid } \\
\text { employed, } \\
q \leq 0.3\end{array}$ & $\begin{array}{l}\text { std. paid } \\
\text { employed, } \\
q>0.3\end{array}$ & $\begin{array}{l}\text { non-std. } \\
\text { paid } \\
\text { employed } \\
q \leq 0.3\end{array}$ & $\begin{array}{l}\text { non-std. } \\
\text { paid } \\
\text { employed } \\
q>0.3\end{array}$ \\
\hline Nnumber of observations & 3,856 & 883 & 30,935 & 16,678 & 2,567 & 1,448 \\
\hline \multicolumn{7}{|l|}{ Means: } \\
\hline Life satisfaction, scale $0-10$ & $\begin{array}{l}7.27 \\
(1.59)\end{array}$ & $\begin{array}{l}6.33 \\
(1.92)\end{array}$ & $\begin{array}{l}7.38 \\
(1.49)\end{array}$ & $\begin{array}{l}6.66 \\
(1.68)\end{array}$ & $\begin{array}{l}7.30 \\
(1.62)\end{array}$ & $\begin{array}{l}6.79 \\
(1.73)\end{array}$ \\
\hline Equivalence income $^{*}$ & $\begin{array}{l}2,233.73 \\
(1,846.76)\end{array}$ & $\begin{array}{l}1,683.80 \\
(1,066.80)\end{array}$ & $\begin{array}{l}1,778.47 \\
(963.22)\end{array}$ & $\begin{array}{l}1,508.55 \\
(712.21)\end{array}$ & $\begin{array}{l}1,460.25 \\
(917.05)\end{array}$ & $\begin{array}{l}1,292.88 \\
(663.59)\end{array}$ \\
\hline Age & $\begin{array}{l}45.42 \\
(9.65)\end{array}$ & $\begin{array}{l}43.95 \\
(9.42)\end{array}$ & $\begin{array}{l}42.65 \\
(10.62)\end{array}$ & $\begin{array}{l}40.78 \\
(10.26)\end{array}$ & $\begin{array}{l}41.26 \\
(12.37)\end{array}$ & $\begin{array}{l}39.65 \\
(11.99)\end{array}$ \\
\hline Years of unemployment & $\begin{array}{l}0.37 \\
(1.00)\end{array}$ & $\begin{array}{l}0.67 \\
(1.46)\end{array}$ & $\begin{array}{l}0.37 \\
(1.06)\end{array}$ & $\begin{array}{l}0.68 \\
(1.46)\end{array}$ & $\begin{array}{l}0.71 \\
(2.02)\end{array}$ & $\begin{array}{l}1.21 \\
(2.41)\end{array}$ \\
\hline Working hours per day & $\begin{array}{l}9.55 \\
(2.47)\end{array}$ & $\begin{array}{l}9.40 \\
(2.57)\end{array}$ & $\begin{array}{l}8.89 \\
(2.03)\end{array}$ & $\begin{array}{l}8.99 \\
(2.1)\end{array}$ & $\begin{array}{l}3.53 \\
(2.12)\end{array}$ & $\begin{array}{l}3.73 \\
(2.24)\end{array}$ \\
\hline Tenure in years & $\begin{array}{l}10.70 \\
(9.08)\end{array}$ & $\begin{array}{l}7.63 \\
(7.73)\end{array}$ & $\begin{array}{l}12.62 \\
(10.33)\end{array}$ & $\begin{array}{l}8.85 \\
(8.83)\end{array}$ & $\begin{array}{l}6.14 \\
(7.07)\end{array}$ & $\begin{array}{l}4.24 \\
(5.58)\end{array}$ \\
\hline \multicolumn{7}{|l|}{ Shares: } \\
\hline Women & $31 \%$ & $31 \%$ & $44 \%$ & $45 \%$ & $86 \%$ & $84 \%$ \\
\hline People owning their home & $64 \%$ & $55 \%$ & $53 \%$ & $47 \%$ & $54 \%$ & $51 \%$ \\
\hline Married & $72 \%$ & $66 \%$ & $68 \%$ & $63 \%$ & $75 \%$ & $69 \%$ \\
\hline Children in the same household & $35 \%$ & $34 \%$ & $32 \%$ & $32 \%$ & $45 \%$ & $43 \%$ \\
\hline Disabled & $4 \%$ & $2 \%$ & $6 \%$ & $6 \%$ & $5 \%$ & $6 \%$ \\
\hline Recent overnight stays in hospital ${ }^{* *}$ & $7 \%$ & $7 \%$ & $8 \%$ & $8 \%$ & $10 \%$ & $9 \%$ \\
\hline
\end{tabular}

Source: SOEP 1999, 2001, 2003, 2005, 2007, 2009.

Note: Standard deviations in parentheses. "monthly, at 2006 Euros, ${ }^{* *}$ during the previous 12 months.

Running a business is always associated with considerably higher equivalence income available and higher wealth in terms of home ownership than working for an employer. When the probability of losing work exceeds $30 \%$, these advantages of self-employment are smaller compared to $q \leq 0.3$. Self-employed workers are also more likely to be older, married and male, work more hours and are less likely to be disabled. Standard salaried workers are employed somewhat longer than self-employed workers run their businesses. Only when $q \leq 0.3$ are small differences regarding living with children in the same household and overnight stays in hospital during the last twelve months statistically significant. In general, 
observations of self-employed and standard paid-employed workers do not differ significantly with regard to unemployment experience. Taken as a whole, the figures of Table 1 suggest that self-employed workers are comparable to standard rather than to non-standard paidemployed workers. Hence, standard salaried workers form the preferred comparison group for the following analysis.

Self-employment has different manifestations. For instance, in the 2009 subsample, almost one third of the self-employed are freelancers with academic degrees, about $61 \%$ are other business owners and there is a very small number of farmers and family co-workers of business owners. One half of the self-employed (49.4\%) employ other workers while the other half work alone (50.6\%). 8.2\% employ ten or more people. Regarding business sectors, most of the self-employed provide services such as health services, financial services and many more. Retailers (16\%) as well as construction businesses (14\%) which build housing, plants, machines and vehicles are relevant as well. $8 \%$ of the self-employed run firms that produce other commodities as craftsmen or manufacturers. The agricultural sector as well as mining, energy and transportation account for the rest. These figures vary only slightly over time. At a later stage, robustness checks will address these different kinds of selfemployment.

\subsection{Multivariate analyses}

The mean comparisons show that self-employed workers report much lower life satisfaction than paid-employed workers when the probability of losing work is relatively high. Multiple regression analyses considering individual fixed effects can shed light on the question of whether this result is related to other characteristics presented in Table 1 or originate from time-invariant factors such as personality traits. As described in detail in Subsection 3.1, the life satisfaction effects of interactions between employment status and the probability of losing work are therefore estimated and compared. Controls include employment status, socio-demographic characteristics and job characteristics. The corresponding results are presented in Table 2. The first specification (I-1) only controls for time effects. Selfemployment and non-standard employment reduce life satisfaction slightly compared to the reference category, standard paid employed. Each interaction of the probability of losing work (here $100 \%$ increases) and the three types of work is negatively related to life satisfaction. The differences between the coefficients of these interactions reveal that the self-employed 
suffer much more from expecting a loss of work than standard and non-standard paidemployed workers. The following two differences are significant at the $1 \%$ level:

self-employed $\times\left(\frac{q}{100}\right)-$ std. paid employed $\times\left(\frac{q}{100}\right)=-1.959-(-1.426)=-0.533$

self-employed $\times\left(\frac{q}{100}\right)-$ non std. paid employed $\times\left(\frac{q}{100}\right)=-1.959-(-1.426)=-1.118$

Controlling for individual fixed effects (Specification I-2) weakens the effects of the probability of losing work on all of the types of work as well as the differences between them. Nevertheless, an increase in the probability of losing work of $100 \%$ lowers life satisfaction when self-employed by 0.329 points more $(p<0.05)$ than when standard paid employed. The difference between non-standard dependent employment and self-employment is also substantial and even significant at the $1 \%$ level. These patterns neither change when further controls are added in Specification I-3 (work and socio-demographic characteristics) nor when income and wealth are taken into account as well (Specification I-4).

The estimation results also cast light on the question whether self-employment is a more promising employment status than dependent employment (e.g. Binder and Coad 2013). Remarkably, introducing individual fixed effects turns the general effect of self-employment on life satisfaction from negative (I-1) to positive (I-2). Hence, time invariant worker characteristics might explain why self-employed people are not happier than salaried workers, although the same people are happier when they are self-employed instead of paid employed. Furthermore, it is shown that the current likelihood of losing work modifies these differences. For instance, the fourth model specification predicts that a $100 \%$ increase in the probability of losing work reduces the well-being of the self-employed by 0.346 points more than the wellbeing of salaried workers. The positive effect of being self-employed (0.176) is hence neutralised by a $51 \%$ increase in the probability of losing work.

Further findings are in line with previous happiness research (e.g. Weimann et al. in press). Across all of the specifications, indicators of poor health reduce well-being (disabled, overnight stays in hospital) whereas income and wealth (home ownership) benefit well-being. Being divorced and married (reference category) seem to be the most promising marital states. Non-standard dependent employment is associated with lower life satisfaction than standard dependent employment. 
Table 2: OLS regression results for the first identification strategy

\begin{tabular}{|c|c|c|c|c|}
\hline Specification & I-1 & I-2 & I-3 & $\mathrm{I}-4$ \\
\hline self-employed & $\begin{array}{c}-0.101^{* * *} \\
(0.028)\end{array}$ & $\begin{array}{c}0.183^{* * *} \\
(0.064)\end{array}$ & $\begin{array}{c}0.177^{* * *} \\
(0.065)\end{array}$ & $\begin{array}{c}0.176^{* * *} \\
(0.064)\end{array}$ \\
\hline non-standard paid employed & $\begin{array}{c}-0.130^{* * *} \\
(0.035)\end{array}$ & $\begin{array}{c}-0.156^{* * *} \\
(0.052)\end{array}$ & $\begin{array}{c}-0.171^{* * *} \\
(0.054)\end{array}$ & $\begin{array}{c}-0.148^{* * *} \\
(0.054)\end{array}$ \\
\hline self-employed × $(q / 100)$ & $\begin{array}{c}-1.959^{* * *} \\
(0.138)\end{array}$ & $\begin{array}{c}-0.874^{* * *} \\
(0.150)\end{array}$ & $\begin{array}{c}-0.880^{* * *} \\
(0.148)\end{array}$ & $\begin{array}{c}-0.876^{* * *} \\
(0.146)\end{array}$ \\
\hline standard paid employed $\times(q / 100)$ & $\begin{array}{c}-1.426^{* * *} \\
(0.032)\end{array}$ & $\begin{array}{c}-0.546^{* * *} \\
(0.038)\end{array}$ & $\begin{array}{c}-0.545^{* * *} \\
(0.038)\end{array}$ & $\begin{array}{c}-0.530^{* * *} \\
(0.038)\end{array}$ \\
\hline non-standard paid employed $\times(q / 100)$ & $\begin{array}{c}-0.841^{* * *} \\
(0.103)\end{array}$ & $\begin{array}{c}-0.277^{* *} \\
(0.112)\end{array}$ & $\begin{array}{c}-0.280^{* *} \\
(0.112)\end{array}$ & $\begin{array}{c}-0.259^{* *} \\
(0.112)\end{array}$ \\
\hline age $^{2}$ & & & $\begin{array}{l}0.000^{*} \\
(0.000)\end{array}$ & $\begin{array}{c}0.000^{* *} \\
(0.000)\end{array}$ \\
\hline divorced & & & $\begin{array}{l}0.016 \\
(0.057)\end{array}$ & $\begin{array}{l}0.043 \\
(0.058)\end{array}$ \\
\hline separated & & & $\begin{array}{c}-0.310^{* * *} \\
(0.070)\end{array}$ & $\begin{array}{c}-0.283^{* * *} \\
(0.070)\end{array}$ \\
\hline widowed & & & $\begin{array}{c}-0.618^{* * *} \\
(0.208)\end{array}$ & $\begin{array}{c}-0.611^{* * *} \\
(0.207)\end{array}$ \\
\hline unwed & & & $\begin{array}{c}-0.108^{* *} \\
(0.044)\end{array}$ & $\begin{array}{c}-0.095^{* *} \\
(0.043)\end{array}$ \\
\hline children living in household: yes & & & $\begin{array}{l}0.022 \\
(0.024)\end{array}$ & $\begin{array}{l}0.035 \\
(0.024)\end{array}$ \\
\hline recent overnight stays in hospital: yes & & & $\begin{array}{c}-0.140^{* * *} \\
(0.025)\end{array}$ & $\begin{array}{c}-0.138^{* * *} \\
(0.025)\end{array}$ \\
\hline disabled: yes & & & $\begin{array}{c}-0.332^{* * *} \\
(0.059)\end{array}$ & $\begin{array}{c}-0.328^{* * *} \\
(0.059)\end{array}$ \\
\hline years of unemployment experience & & & $\begin{array}{c}-0.021 \\
(0.026)\end{array}$ & $\begin{array}{l}-0.004 \\
(0.026)\end{array}$ \\
\hline new job & & & $\begin{array}{l}0.019 \\
(0.030)\end{array}$ & $\begin{array}{l}0.024 \\
(0.022)\end{array}$ \\
\hline tenure & & & $\begin{array}{l}-0.005 \\
(0.004)\end{array}$ & $\begin{array}{l}-0.005 \\
(0.004)\end{array}$ \\
\hline tenure $^{2}$ & & & $\begin{array}{l}0.000 \\
(0.000)\end{array}$ & $\begin{array}{l}0.000 \\
(0.000)\end{array}$ \\
\hline working hours, difference to eight per day & & & $\begin{array}{l}-0.004 \\
(0.005)\end{array}$ & $\begin{array}{c}-0.009^{*} \\
(0.005)\end{array}$ \\
\hline log. equivalence income at 2006 prices & & & & $\begin{array}{c}0.341^{* * *} \\
(0.030)\end{array}$ \\
\hline home ownership & & & & $\begin{array}{c}0.074^{* *} \\
(0.029)\end{array}$ \\
\hline time effects & yes & yes & yes & yes \\
\hline individual fixed effects & & yes & yes & yes \\
\hline Constant & $\begin{array}{c}7.395^{* * *} \\
(0.018)\end{array}$ & $\begin{array}{c}7.026^{* * *} \\
(0.017)\end{array}$ & $\begin{array}{c}6.616^{* * *} \\
(0.297)\end{array}$ & $\begin{array}{c}3.995^{* * *} \\
(0.369)\end{array}$ \\
\hline Observations & 56,397 & 56,397 & 56,397 & 56,397 \\
\hline number of persons & 19,436 & 19,436 & 19,436 & 19,436 \\
\hline adjusted $\mathrm{R}^{2}$ & 0.049 & 0.029 & 0.033 & 0.038 \\
\hline
\end{tabular}

Source: SOEP 1999, 2001, 2003, 2005, 2007, 2009.

Note: ${ }^{*} p<0.1,{ }^{* *} p<0.05,{ }^{* * *} p<0.01$. Robust standard errors in parentheses. The dependent variable is life satisfaction. The hypothetical reference group (Specification I-4) is standard paid employed, reports $0 \%$ probability of losing work, is 0 years old, married, not living with children in the same household, not disabled, did not stay overnight in hospital during the last 12 months, experienced 0 years of unemployment during the whole working life, is longer paid employed or self-employed than since the previous SOEP interview, reports 0 years of tenure, works 8 hours per day, was interviewed in 2009, does not receive equivalence income and does not own its home. 


\subsection{Subgroup analyses and the role of personality}

Specification (I-4) is estimated based on more homogenous subsamples in order to improve the comparability of both self-employed and salaried workers as well as within the group of the self-employed. Table 3 summarises the main finding of each subgroup analysis, the difference between the coefficients of the interaction of the probability of losing work with being self-employed and the interaction of the probability of losing work with being standard paid employed. Table A1 presents the estimation results of all subgroup analyses in detail.

Table 3: Main findings of subgroup analyses, first identification strategy

\begin{tabular}{lll} 
& $\begin{array}{r}\text { self-employed } \times(q / 100)- \\
\text { standard paid employed } \times(q / 100)\end{array}$ \\
\hline (1) whole sample & $-0.346^{* *}(0.150)$ \\
(2) age 25-60 & $-0.387^{* *}(0.159)$ \\
(3) no civil servants & $-0.321^{* *}(0.151)$ \\
(4) men & $-0.420^{* *}(0.176)$ \\
(5) women & -0.106 & $(0.276)$ \\
(6) self-employed: employer & -0.306 & $(0.250)$ \\
(7) self-employed: no employees & $-0.504^{* *}(0.217)$ \\
(8) self-employed: freelancer & -0.381 & $(0.251)$ \\
(9) self-employed: owner & $-0.450^{* *}(0.192)$ \\
(10) self-employed: services & $-0.423^{*}$ & $(0.228)$ \\
(11) self-employed: not services & $-0.381^{*}$ & $(0.207)$ \\
\hline \hline
\end{tabular}

Source: SOEP 1999, 2001, 2003, 2005, 2007, 2009.

Note: ${ }^{*} p<0.1,{ }^{* *} p<0.05^{* * *} p<0.01$. Robust standard errors in parentheses. The results presented in the table are differences in the effects of interactions of the probability of losing work with selfemployment and standard dependent employment. The underlying OLS estimates are presented in Table A1.

The $1^{\text {st }}$ row of Table 3 allows for comparisons to be made with the main finding by analysing the whole sample. To begin with, the sample is made more homogenous with respect to age. For instance, the timing of the retirement of self-employed and salaried workers may vary because they are treated differently by public pension insurance. The age group is therefore restricted to respondents that are between 25 and 60 years old (Table $3,2^{\text {nd }}$ row). A further check excludes civil servants (Table $3,3^{\text {rd }}$ row), which is an exceptional subgroup of salaried workers in many respects and especially regarding job security. Both analyses yield the same qualitative findings as before. Splitting the sample into subsamples, one male and one female (Table $3,4^{\text {th }}$ and $5^{\text {th }}$ rows), reveals that the difference in the reaction of life satisfaction to an 
increase in the probability of losing work between self-employed and salaried workers is mainly driven by male workers.

Further subgroup analyses shed light on different manifestations of self-employment. It turns out that self-employed workers who do not employ others suffer in particular from expecting a loss of work in the near future (Table $3,6^{\text {th }}$ and $7^{\text {th }}$ rows). This finding does not speak in favour of the supposition that the necessity to dismiss employees explains the higher welfare cost of losing self-employment compared to losing dependent employment. As described above, self-employed workers in the sample are freelancers with academic degrees, farmers, family co-workers and other business owners. The first and the last group are large enough to run separate regressions (Table $3,8^{\text {th }}$ and $9^{\text {th }}$ rows). It turns out that other business owners especially suffer from an increase in the probability of losing work. The effect for a subsample of freelancers is comparable to the average effect for all self-employed workers, but the result is not statistically significant. The results for freelancers and other business owners also make it clear that including family co-workers in the observations of selfemployment does not drive the findings described so far. Finally, a weak sector difference emerges in that the well-being of self-employed workers whose businesses provide services reacts slightly more to the probability of losing work than the well-being of other selfemployed workers (Table $3,10^{\text {th }}$ and $11^{\text {th }}$ rows).

Altogether, the subgroup analyses indicate that the main finding of the first estimation approach seems to be generally valid. None of the differences between the interactions of the probability of losing work with being paid employed and with being self-employed point in a direction that is different to the results obtained from analysing the whole sample. This also applies to all of the further results (Table A1). In particular, being self-employed instead of being paid employed seems to increase life satisfaction. The highest benefits in this respect appear in the cases of self-employed workers with employees and freelancers with academic degrees. Being non-standard paid employed instead of standard paid employed reduces wellbeing. Furthermore, the negative effect of the probability of losing work on life satisfaction is very robust. It is also stronger for men than for women.

It is conceivable that some kind of entrepreneurial personality leads to the relatively high cost of losing work and hence drives the results obtained so far. To test this conjecture, it is analysed whether the different reactions of self-employed and standard salaried workers' life satisfaction to a higher probability of losing work vary depending on personality traits. For 
instance, it is tested whether observations of both types of work that are hardly risk averse (observations to the left of the first quartile of the distribution of risk aversion within the sample) vary differently in the loss of well-being compared to observations with middle or high risk aversion (high: observations to the right of the third quartile, middle: rest). This is repeated for openness to experience, conscientiousness, agreeableness, extraversion, neuroticism as well as internal and external locus of control. The results of these analyses reveal that there is no personality trait that is specifically related to the difference in the reaction of life satisfaction of self-employed and salaried workers to the probability of losing work. ${ }^{5}$

\section{Life satisfaction and unemployment}

\subsection{Descriptive insights}

As a first step in the second identification strategy, the averages of life satisfaction before and after different terminations of work are documented. In the process, some light is also shed on the assumption that self-employed workers who become unemployed had no intention of this happening. People who cease self-employment and become unemployed are compared to two groups which represent different transitions from dependent employment to unemployment. For this analysis resignations and plant closures are chosen as it is suspected that they identify endogenous and exogenous job terminations best (Chadi and Hetschko 2014). Figure 1 displays the different progressions at four points in time, from $t=-2$ (second last SOEP interview before job termination) to $t=1$ (second SOEP interview afterwards). Workers are employed at $t=-2$ and $t=-1$, terminate jobs between $t=-1$ and $t=0$, and are unemployed at $t=0$ and $t=1$. The period between two points in time covers approximately one year. The data used is not restricted to the waves in which reasons for job terminations are ascertained in the same manner in order to ensure the largest database available for this four-year analysis.

Self-employed workers start at the lowest level of life satisfaction at $t=-2$ compared to the two groups of paid employees. This result is in line with the findings of the first estimation approach: If work is at risk for the next two years, self-employed workers report

\footnotetext{
${ }^{5}$ Not every SOEP wave includes information on these personality traits. If information is not available, it is transferred from the nearest wave including it, assuming personality traits are stable over relatively short periods of time (maximum of four years).
} 
lower well-being than salaried workers. For all of the three groups, subjective well-being declines from periods $t=-2$ to $t=-1$. An even more substantial drop follows from $t=-1$ to $t=0$. However, the three groups differ with respect to the magnitude of this change. The selfemployed experience the biggest loss of well-being, followed by workers witnessing plant closures and then those who resign. The gaps in life satisfaction between the three groups diminish slightly between $t=0$ and $t=1$.

Figure 1: Life satisfaction trajectories around the transition to unemployment

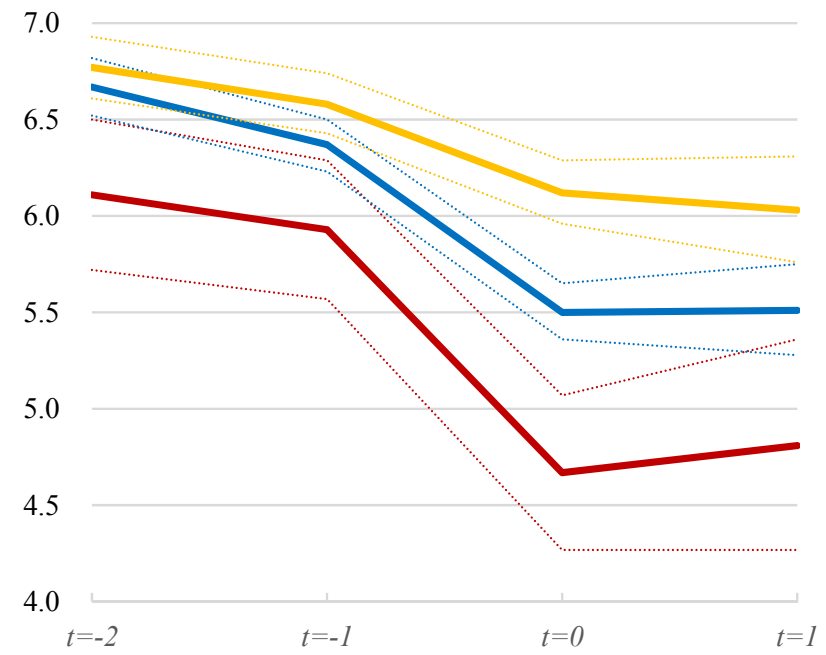

Source: SOEP 1984-2012.

Note: The diagram shows trajectories of life satisfaction around the transition from selfemployment/dependent employment to unemployment. The transition happens between $t=-1$ and $t=0$. Red lines denote self-employed people. Orange (blue) lines denote salaried workers who resign (lose their jobs due to plant closure). Dotted lines illustrate $95 \%$ confidence intervals.

The assumption that self-employed workers who terminate their jobs and become unemployed do not do this intentionally might be susceptible to criticism. In this context, it is interesting to note that this group suffers a greater loss in well-being than paid employees who terminate their jobs due to an exogenous trigger (plant closure) and that endogenous job terminations (resignations) show the most favourable progression. If the reasons for giving up self-employment and becoming unemployed were mostly endogenous, one would expect a trajectory similar to that of resignations of salaried workers rather than that of job losses due to plant closures.

Table 4 displays several characteristics of people who terminate work and become unemployed. The observations conform with the sample from which the main results of the 
second estimation approach are obtained (the results are described in the following two subsections). They are thus restricted to being standard paid employed or self-employed at $t=-1$ and to being unemployed at $t=0$. The reasons for terminating work in the observations are ceased self-employment, plant closure, resignation, reaching the end date of a fixed-term contract and being dismissed. These reasons are consistently retrieved.

Table 4: Descriptive statistics - second approach

\begin{tabular}{llllll} 
Reason for the loss of work & $\begin{array}{l}\text { ceased self- } \\
\text { employment }\end{array}$ & $\begin{array}{l}\text { plant } \\
\text { closure }\end{array}$ & dismissed & $\begin{array}{l}\text { end date } \\
\text { reached }\end{array}$ & resignation \\
\hline Observations & 100 & 657 & 2,125 & 860 & 425 \\
Life satisfaction & $4.7(-1.4)$ & $5.5(-0.9)$ & $5.7(-0.7)$ & $5.7(-0.7)$ & $6.1(-0.4)$ \\
Monthly equivalence income at 2006 Euros & $980(-509)$ & $1,095(-99)$ & $1,102(-175)$ & $1,103(-163)$ & $1,257(-232)$ \\
Age & 43.7 & 44.3 & 41.6 & 39.7 & 39.3 \\
Unemployment experience in years & 2.2 & 1.1 & 1.5 & 2.5 & 1.2 \\
Share of being married & $59 \%(-3 \%)$ & $75 \%(1 \%)$ & $63 \%(0 \%)$ & $57 \%(0 \%)$ & $63 \%(-1 \%)$ \\
Share of living with children in household & $30 \%(-3 \%)$ & $32 \%(-3 \%)$ & $32 \%(-2 \%)$ & $35 \%(-1 \%)$ & $37 \%(-1 \%)$ \\
Share of people who own their home & $35 \%(0 \%)$ & $38 \%(1 \%)$ & $34 \%(1 \%)$ & $32 \%(0 \%)$ & $34 \%(0 \%)$ \\
Share of women & $34 \%$ & $47 \%$ & $42 \%$ & $53 \%$ & $60 \%$
\end{tabular}

Source: SOEP 1991-1998 and 2001-2012.

Note: The figures describe characteristics at $t=0$, the first interview after becoming unemployed (changes to $t=-1$ in parentheses).

Besides life satisfaction at $t=0$ and the change in life satisfaction between $t=-1$ and $t=0$, two characteristics differ sharply between workers losing self-employment and all of the groups losing dependent employment. The former lose much more income and are less often female. A slight difference appears with regard to living with children in the same household, which is less prevalent when self-employed workers lose their work. Self-employment and a fixed-term contract prior to unemployment are less frequently associated with being married and more often with previous unemployment experience.

\subsection{Multivariate analyses}

As described in detail in Subsection 3.2, the second estimation approach is a multivariate analysis explaining the change in life satisfaction between $t=-1$ and $t=0$. It includes reasons for job terminations and controls for changes in life between $t=-1$ and $t=0$ (e.g. marriage) as well as for individual characteristics (e.g. female). The results are presented in Table 5. The first specification of the second identification strategy (II-1) includes reasons for job 
termination and the year of the interview $(t=0)$. At the beginning $\left(1^{\text {st }}\right.$ Column $)$, the sample is not restricted to workers that are unemployed at $t=0$. Transitions into new jobs (standard or non-standard dependent employment), into self-employment or into the status out of labour force are also possible. It turns out that the reason why work is terminated is strongly related to the simultaneous change in life satisfaction. Only resignations seem to increase well-being. Members of the reference group who lost their jobs involuntarily due to plant closures suffer from the termination of employment and do not differ considerably from workers who reach the end date of their contract, are dismissed or cease self-employment. Although some selfemployed workers may terminate voluntarily because they sell their business and retire or switch to a promising paid job, the average change in life satisfaction does not differ from the reference group, consisting of people who terminate employment involuntarily.

When the sample is restricted by excluding transitions to any kind of work (Table $5,2^{\text {nd }}$ column), self-employed and dismissed workers are again more or less comparable to the reference group of job losses due to plant closure. People who resign or, although less pronounced, reach the end date of their contract experience less sorrowful terminations of employment. Finally, we restrict the sample to workers who are unemployed at $t=0$, expecting that this step disentangles voluntary from involuntary terminations of selfemployment. Now, the change of life satisfaction that accompanies terminating selfemployment is much more negative than that associated with transitions from dependent employment to unemployment due to plant closures. In line with the findings from the first identification approach, losing work turns out to be a much more negative life event for the self-employed than for salaried workers.

Further controls influence the differences between the effects of people's reasons for terminating jobs only slightly (Table 5, Specifications II-2, II-3). Introducing a control for the change in income causes the most remarkable change in the effect of ceased self-employment. Hence, monetary reasons may explain to some extent why the self-employed suffer much more from losing work than salaried workers, but non-pecuniary factors are likely to matter as well. The effect of terminated self-employment is lowered, but stays significantly negative even when controlling for changes in income. Alternative controls for income such as the relative income change compared to $t=-1$, levels of equivalence income at $t=0$ or $t=-1$, being in debt at $t=0$ as well as combinations of these measures do not lead to further insights. 
Table 5: OLS regression results of the second estimation approach

\begin{tabular}{|c|c|c|c|c|c|}
\hline $\begin{array}{l}\text { Employment status in } t=0 \\
\text { Specification of (II) }\end{array}$ & $\begin{array}{l}\text { all states } \\
(\mathrm{II}-1)\end{array}$ & $\begin{array}{l}\text { not working } \\
\text { (II-1) }\end{array}$ & $\begin{array}{l}\text { unemployed } \\
\text { (II-1) }\end{array}$ & $\begin{array}{l}\text { unemployed } \\
\text { (II-2) }\end{array}$ & $\begin{array}{l}\text { unemployed } \\
\text { (II-3) }\end{array}$ \\
\hline Ceased self-employment & $\begin{array}{l}-0.026 \\
(0.112)\end{array}$ & $\begin{array}{l}0.063 \\
(0.155)\end{array}$ & $\begin{array}{c}-0.665^{* * *} \\
(0.240)\end{array}$ & $\begin{array}{c}-0.615^{* *} \\
(0.239)\end{array}$ & $\begin{array}{c}-0.542^{* *} \\
(0.239)\end{array}$ \\
\hline Resigned & $\begin{array}{l}0.432^{* * *} \\
(0.051)\end{array}$ & $\begin{array}{l}0.557^{* * *} \\
(0.085)\end{array}$ & $\begin{array}{l}0.479^{* * *} \\
(0.124)\end{array}$ & $\begin{array}{l}0.518^{* * *} \\
(0.125)\end{array}$ & $\begin{array}{l}0.536^{* * *} \\
(0.125)\end{array}$ \\
\hline Dismissed & $\begin{array}{l}-0.05 \\
(0.056)\end{array}$ & $\begin{array}{c}0.026 \\
(0.080)\end{array}$ & $\begin{array}{c}0.138 \\
(0.089)\end{array}$ & $\begin{array}{l}0.175^{* *} \\
(0.089)\end{array}$ & $\begin{array}{l}0.173^{*} \\
(0.089)\end{array}$ \\
\hline Reached end date of contract & $\begin{array}{c}0.015 \\
(0.063)\end{array}$ & $\begin{array}{l}0.152^{*} \\
(0.089)\end{array}$ & $\begin{array}{l}0.212^{* *} \\
(0.104)\end{array}$ & $\begin{array}{l}0.242^{* *} \\
(0.104)\end{array}$ & $\begin{array}{l}0.233^{* *} \\
(0.104)\end{array}$ \\
\hline Female & & & & $\begin{array}{l}0.179^{* * *} \\
(0.064)\end{array}$ & $\begin{array}{l}0.163^{* *} \\
(0.064)\end{array}$ \\
\hline Age, difference to 45 years & & & & $\begin{array}{c}0.009^{* * *} \\
(0.003)\end{array}$ & $\begin{array}{l}0.009^{* * *} \\
(0.003)\end{array}$ \\
\hline Marriage & & & & $\begin{array}{l}0.487^{*} \\
(0.278)\end{array}$ & $\begin{array}{l}0.467^{*} \\
(0.278)\end{array}$ \\
\hline Separation & & & & $\begin{array}{l}-0.188 \\
(0.300)\end{array}$ & $\begin{array}{l}-0.167 \\
(0.303)\end{array}$ \\
\hline Divorce & & & & $\begin{array}{l}-0.075 \\
(0.401)\end{array}$ & $\begin{array}{l}-0.024 \\
(0.401)\end{array}$ \\
\hline Death of spouse & & & & $\begin{array}{c}-2.729^{* * *} \\
(0.802)\end{array}$ & $\begin{array}{c}-2.646^{* * *} \\
(0.776)\end{array}$ \\
\hline Change in 'children in household: yes' & & & & $\begin{array}{l}0.525^{* *} \\
(0.220)\end{array}$ & $\begin{array}{c}0.586^{* * *} \\
(0.225)\end{array}$ \\
\hline Change in equivalence income, 2006 prices & & & & & $\begin{array}{c}0.214^{* * *} \\
(0.075)\end{array}$ \\
\hline Change in home ownership & & & & & $\begin{array}{c}0.266 \\
(0.170)\end{array}$ \\
\hline Year of $t=0$ & yes & yes & yes & yes & yes \\
\hline Constant & $\begin{array}{c}-0.319^{* * *} \\
(0.098)\end{array}$ & $\begin{array}{c}-0.670^{* * *} \\
(0.144)\end{array}$ & $\begin{array}{c}-0.820^{* * *} \\
(0.180)\end{array}$ & $\begin{array}{c}-0.915^{* * *} \\
(0.183)\end{array}$ & $\begin{array}{c}-0.873^{* * *} \\
(0.182)\end{array}$ \\
\hline Observations & 12,605 & 6,041 & 4,167 & 4,167 & 4,167 \\
\hline Adjusted $\mathrm{R}^{2}$ & 0.020 & 0.018 & 0.018 & 0.027 & 0.030 \\
\hline
\end{tabular}

Source: SOEP 1991-1998 and 2001-2012.

Note: ${ }^{*} p<0.1,{ }^{* *} p<0.05^{* * *} p<0.01$. Robust standard errors in parentheses. The dependent variable is the change in life satisfaction between $t=-1$ and $t=0$. The period between the two points in time covers approximately one year. At $t=-1$, all of the observations are either self-employed or paid employed. The hypothetical reference group (II-3) terminates its initial job due to plant closure between the 2005 and the 2006 SOEP interview, is 45 years old and male. It does not experience changes in equivalence income, home ownership, marital status, living with children in the same household between $t=-1$ and $t=0$.

\subsection{Robustness and reasons}

The validity of the assumption that self-employed workers who become unemployed suffer from exogenous loss of work can be strengthened further. Following Chadi (2010) as well as Bonsang and Klein (2012), use is made of information from unemployed workers about their intentions to return to employment and restrict the sample to those people who state that they definitely intend to be reemployed in the future. In the end, the sample may only consist of 
workers who feel involuntarily unemployed. Specification (II-3) is re-estimated based on this subsample. The results are presented in Table 6 (Column 2; Column 1 allows for comparison to the results of Table 5). The differences between former self-employed and paid-employed workers are somewhat greater compared to the regressions based on the whole sample, which strengthens the interpretation of the findings documented up to here. The more plausible it is that self-employed workers lose their work involuntarily, the more the misery of losing work differs between self-employed and salaried workers.

Poor health might explain simultaneously why people give up running their own business, become unemployed and lose well-being between $t=-1$ and $t=0$. Controls such as disability or overnight stays in hospital can only be tested using reduced samples as the respective information is not available for the whole investigation period. The corresponding regressions yield the same findings as before (Table 6, Columns 3 and 4). Columns 5 and 6 display separate estimation results for unemployed men and women based on (II-3) which do not differ substantially.

The self-employed often do not contribute to unemployment insurance. Thus they might be more likely to rely on social benefits when they become unemployed, unless they benefit more from other sources of income, such as spouses' earnings. In consequence, violating the social norm of making one's own living is a potential driver of a difference in the psychological cost of losing work between salaried and self-employed workers. A further control for being a welfare recipient at $t=0$ is included in order to test this hypothesis (Table 6, Column 7). This analysis must be conducted on a reduced sample because information on social benefits is not available for the whole investigation period. It turns out that being a welfare recipient does not explain the negative effect of terminating self-employment.

Finally, it is investigated whether either losing possible advantages of self-employment (e.g. more pleasant job characteristics) or the process of losing self-employment and being unemployed after self-employment (e.g. stronger feeling of personal failure) explains the difference in the misery of losing work. The mean comparison at the beginning of this section obviously supports the second conjecture. Losing work is more harmful for the self-employed although they start at a much lower level of life satisfaction already before they become unemployed. Indeed, additionally controlling for the level of life satisfaction at $t=0$ in model (II-3) explains the whole negative effect of ceased self-employment on the change in well- 
being between $t=0$ and $t=-1$ (Table 6, Column 8). Hence, the consequences of becoming unemployed might account for the extraordinary suffering of the self-employed.

Table 6: Further analyses based on second estimation approach

\begin{tabular}{|c|c|c|c|c|c|c|c|c|}
\hline & $\begin{array}{c}(1) \\
\text { whole } \\
\text { sample }\end{array}$ & $\begin{array}{l}(2) \\
\text { willing to } \\
\text { return to } \\
\text { work }\end{array}$ & $\begin{array}{c}(3) \\
\text { poor } \\
\text { health: } \\
\text { disability }\end{array}$ & $\begin{array}{l}\text { (4) } \\
\text { poor health: } \\
\text { recent } \\
\text { hospital stay }\end{array}$ & $\begin{array}{c}(5) \\
\text { women }\end{array}$ & $\begin{array}{l}(6) \\
\text { men }\end{array}$ & $\begin{array}{c}(7) \\
\text { welfare } \\
\text { recipient }\end{array}$ & $\begin{array}{l}\text { (8) } \\
\text { level of life } \\
\text { satisfaction }\end{array}$ \\
\hline Ceased self-employment & $\begin{array}{l}-0.542^{* *} \\
(0.239)\end{array}$ & $\begin{array}{c}-0.711^{* *} \\
(0.315)\end{array}$ & $\begin{array}{c}-0.547^{* *} \\
(0.244)\end{array}$ & $\begin{array}{c}-0.541^{* *} \\
(0.244)\end{array}$ & $\begin{array}{l}-0.567 \\
(0.394)\end{array}$ & $\begin{array}{l}-0.551^{*} \\
(0.309)\end{array}$ & $\begin{array}{l}-0.526^{* *} \\
(0.260)\end{array}$ & $\begin{array}{l}-0.008 \\
(0.190)\end{array}$ \\
\hline Resigned & $\begin{array}{l}0.536^{* * *} \\
(0.125)\end{array}$ & $\begin{array}{l}0.347^{* *} \\
(0.156)\end{array}$ & $\begin{array}{l}0.420^{* * *} \\
(0.125)\end{array}$ & $\begin{array}{l}0.427^{* * *} \\
(0.126)\end{array}$ & $\begin{array}{l}0.508^{* * *} \\
(0.170)\end{array}$ & $\begin{array}{l}0.515^{* * *} \\
(0.190)\end{array}$ & $\begin{array}{c}0.404^{* * *} \\
(0.138)\end{array}$ & $\begin{array}{l}0.212^{* *} \\
(0.103)\end{array}$ \\
\hline Dismissed & $\begin{array}{l}0.173^{*} \\
(0.089)\end{array}$ & $\begin{array}{c}0.060 \\
(0.106)\end{array}$ & $\begin{array}{l}0.128 \\
(0.092)\end{array}$ & $\begin{array}{c}0.140 \\
(0.092)\end{array}$ & $\begin{array}{c}0.215 \\
(0.131)\end{array}$ & $\begin{array}{c}0.121 \\
(0.122)\end{array}$ & $\begin{array}{c}0.160 \\
(0.100)\end{array}$ & $\begin{array}{c}0.109 \\
(0.073)\end{array}$ \\
\hline $\begin{array}{l}\text { Reached end date of } \\
\text { fixed-term contract }\end{array}$ & $\begin{array}{l}0.233^{* *} \\
(0.104)\end{array}$ & $\begin{array}{c}0.137 \\
(0.121)\end{array}$ & $\begin{array}{l}0.201^{*} \\
(0.107)\end{array}$ & $\begin{array}{l}0.214^{* *} \\
(0.107)\end{array}$ & $\begin{array}{l}0.233 \\
(0.153)\end{array}$ & $\begin{array}{c}0.194 \\
(0.143)\end{array}$ & $\begin{array}{l}0.238^{* *} \\
(0.115)\end{array}$ & $\begin{array}{l}0.183^{* *} \\
(0.086)\end{array}$ \\
\hline Disability & & & $\begin{array}{c}0.072 \\
(0.136)\end{array}$ & & & & & \\
\hline $\begin{array}{l}\text { Overnight stays in } \\
\text { hospital }\end{array}$ & & & & $\begin{array}{l}-0.145 \\
(0.105)\end{array}$ & & & & \\
\hline Social benefits at $t=0$ & & & & & & & $\begin{array}{l}-0.135 \\
(0.117)\end{array}$ & \\
\hline Life satisfaction at $t=0$ & & & & & & & & $\begin{array}{l}0.592^{* * *} \\
(0.015)\end{array}$ \\
\hline Controls as in II-3 & yes & yes & yes & yes & yes & yes & yes & yes \\
\hline Time fixed effects & yes & yes & yes & yes & yes & yes & yes & yes \\
\hline Constant & $\begin{array}{c}-0.873^{* * *} \\
(0.182)\end{array}$ & $\begin{array}{l}-1.007^{* * *} \\
(0.216)\end{array}$ & $\begin{array}{c}-0.841^{* * *} \\
(0.184)\end{array}$ & $\begin{array}{c}-0.834^{* * *} \\
(0.184)\end{array}$ & $\begin{array}{c}-0.832^{* * *} \\
(0.268)\end{array}$ & $\begin{array}{c}-0.757^{* * *} \\
(0.245)\end{array}$ & $\begin{array}{c}-0.824^{* * *} \\
(0.189)\end{array}$ & $\begin{array}{c}-4.191^{* * *} \\
(0.171)\end{array}$ \\
\hline Observations & 4,167 & 3,036 & 3,754 & 3,762 & 1,906 & 2,261 & 3,245 & 4,167 \\
\hline Adjusted $\mathrm{R}^{2}$ & 0.030 & 0.028 & 0.027 & 0.027 & 0.041 & 0.029 & 0.027 & 0.369 \\
\hline
\end{tabular}

Source: SOEP 1991-1998 and 2001-2012.

Note: ${ }^{*} p<0.1,{ }^{* *} p<0.05,{ }^{* * *} p<0.01$. Robust standard errors in parentheses. The dependent variable is the change in life satisfaction between $t=-1$ and $t=0$. The period between the two points in time covers approximately one year. All of the observations are either self-employed or standard paid employed at $t=-1$ and unemployed at $t=0$. The hypothetical reference group terminates its initial job due to plant closure between the 2005 and the 2006 SOEP interview, is 45 years old and male (except [4]). It does not experience changes in equivalence income, home ownership, marital status, living with children in the same household between $t=-1$ and $t=0$. Moreover, they are not disabled in the case of (2), did not stay in hospital during the previous twelve months in the case of (3) and do not receive social benefits in the case of (6).

\section{Concluding remarks}

Two complementary ways of comparing self-employment and dependent employment with respect to the misery of losing work are employed in this study. The results obtained from each clearly point in the same direction: Losing self-employment is suggested an even more harmful life event than losing dependent employment, which yields the following 
implications. Firstly, the extraordinary misery of losing work might deter people from becoming self-employed. However, this implication is limited by the descriptive finding that self-employed workers are less likely to lose work (see also Hundley 2001). As the total risk may be a function of both the likelihood of losing work and the welfare cost of losing work, it is a priori undetermined whether the hypothetical possibility of losing work, on average, speaks in favour of being self-employed or not.

This view leads to a second implication. It is often assumed that concerns about the security of work or satisfaction with the security of work reflect this total risk (e.g. Geishecker 2012). Under this assumption, it is possible to reconcile seemingly contradicting findings according to which self-employed workers, on average, report lower probabilities of losing work than salaried workers, but are less satisfied with the security of work (Millàn et al. 2013). If the latter is a function of both the probability of losing work and the utility loss of unemployment, the more harmful misery that the self-employed expect in the case of unemployment potentially outweighs the advantage of a lower likelihood of losing work compared to paidemployed workers. With respect to the first implication, the findings of Millàn et al. (2013) hence suggest that, on average, the total risk of losing self-employment is higher than the total risk of losing dependent employment.

Thirdly, the findings contribute one explanation why responses of well-being to increasing uncertainty about work and unemployment vary between individuals (as it has been discussed in regard to the latter by Gielen and van Ours 2014). Both self-employed workers and dependent employed workers suffer from an increase in the probability of losing work and lose life satisfaction considerably when they have lost work, but the former are affected much more. Prior self-employment is hence a personal characteristic that boosts the individual welfare cost of insecurity and unemployment.

A fourth implication is that former self-employed workers do not need to be forced by labour market policy to search for a new job. Overcoming the extraordinary misery of unemployment should be an incentive in itself (Clark 2003, Stutzer and Lalive 2004, Gielen and van Ours 2014). If the suffering of the former self-employed is accompanied by hopelessness and depression, which might hinder them from seeking work, the policy implication would be to provide psychological intervention and coaching rather than to force them to search. 
Fifthly, the findings identify the currently perceived probability of losing work as moderating the overall well-being difference between self-employment and dependent employment. The higher this likelihood is, the less promising running a business is. This result confirms the view of Binder and Coad (2013) that self-employment and dependent employment differ with respect to subjective well-being depending on other factors. In this context, there is, sixthly, a further explanation for the findings of Block and Koellinger (2009) as well as those of Binder and Coad (2013), who show that entrepreneurial happiness suffers from previous unemployment: Increasing insecurity at work is a scarring effect of past unemployment, reducing well-being (Knabe and Rätzel 2011). According to the findings of the present study, this effect may particularly hurt the self-employed and can hence explain why prior unemployment does not lead to a positive well-being effect of self-employment compared to dependent employment while prior dependent employment yields such a difference.

Finally, the results shed some light on the reasons why the self-employed suffer so much from (expecting) the loss of work. They fall to a lower level of life satisfaction than salaried workers rather than starting from a higher one. Hence, the different consequences of losing work play a particular role. It is also shown that, in the process, monetary as well as nonmonetary factors matter. In regard to the latter, neither higher prevalence of being needy nor the necessity to dismiss others has been identified as being of special importance. This prima facie speaks in favour of alternative explanations for the non-pecuniary part of the difference in the welfare cost of losing work. Stronger feelings of personal failure associated with greater distance from one's ideal self as well as worse future employment and financial prospects may account for the extraordinary misery of losing self-employment compared to losing dependent employment. 


\section{Appendix}

\section{Table A1: Subgroup analyses for the first identification strategy}

\begin{tabular}{|c|c|c|c|c|c|c|c|c|c|c|c|}
\hline Subgroup & $\begin{array}{c}(1) \\
\text { whole } \\
\text { sample }\end{array}$ & $\begin{array}{c}(2) \\
\text { age from } \\
25 \text { to } 60\end{array}$ & $\begin{array}{c}(3) \\
\text { no civil } \\
\text { servants }\end{array}$ & $\begin{array}{l}(4) \\
\text { men }\end{array}$ & $\begin{array}{c}(5) \\
\text { women }\end{array}$ & $\begin{array}{c}(6) \\
\text { self- } \\
\text { employed: } \\
\text { employer }\end{array}$ & $\begin{array}{c}(7) \\
\text { self- } \\
\text { employed: } \\
\text { no } \\
\text { employees }\end{array}$ & $\begin{array}{c}(8) \\
\text { self- } \\
\text { employed: } \\
\text { freelancer }\end{array}$ & $\begin{array}{c}\text { (9) } \\
\text { self- } \\
\text { employed: } \\
\text { owners }\end{array}$ & $\begin{array}{c}(10) \\
\text { self- } \\
\text { employed: } \\
\text { services }\end{array}$ & $\begin{array}{c}(11) \\
\text { self- } \\
\text { employed: } \\
\text { not } \\
\text { services }\end{array}$ \\
\hline Self-employed & $\begin{array}{l}0.176^{* * *} \\
(0.064)\end{array}$ & $\begin{array}{l}0.177^{* * *} \\
(0.067)\end{array}$ & $\begin{array}{l}0.171^{* * *} \\
(0.064)\end{array}$ & $\begin{array}{l}0.163^{* *} \\
(0.079)\end{array}$ & $\begin{array}{l}0.184^{*} \\
(0.110)\end{array}$ & $\begin{array}{l}0.168^{*} \\
(0.100)\end{array}$ & $\begin{array}{l}0.342^{* * *} \\
(0.098)\end{array}$ & $\begin{array}{l}0.270^{* *} \\
(0.130)\end{array}$ & $\begin{array}{l}0.194^{* * *} \\
(0.075)\end{array}$ & $\begin{array}{l}0.211^{* *} \\
(0.094)\end{array}$ & $\begin{array}{l}0.177^{* *} \\
(0.084)\end{array}$ \\
\hline $\begin{array}{l}\text { Non-standard paid } \\
\text { employed }\end{array}$ & $\begin{array}{c}-0.148^{* * *} \\
(0.054)\end{array}$ & $\begin{array}{c}-0.167^{* * *} \\
(0.060)\end{array}$ & $\begin{array}{c}-0.163^{* * *} \\
(0.056)\end{array}$ & $\begin{array}{l}-0.201 \\
(0.139)\end{array}$ & $\begin{array}{l}-0.114^{*} \\
(0.059)\end{array}$ & $\begin{array}{l}-0.149^{* *} \\
(0.058)\end{array}$ & $\begin{array}{c}-0.159^{* * *} \\
(0.058)\end{array}$ & $\begin{array}{c}-0.142^{* * *} \\
(0.054)\end{array}$ & $\begin{array}{c}-0.152^{* * *} \\
(0.054)\end{array}$ & $\begin{array}{c}-0.140^{* * *} \\
(0.054)\end{array}$ & $\begin{array}{c}-0.150^{* * *} \\
(0.054)\end{array}$ \\
\hline Self-employed $\times(q / 100)$ & $\begin{array}{c}-0.876^{* * *} \\
(0.146)\end{array}$ & $\begin{array}{l}-0.961^{* * *} \\
(0.155)\end{array}$ & $\begin{array}{c}-0.868^{* * *} \\
(0.147)\end{array}$ & $\begin{array}{c}-0.999^{* * *} \\
(0.171)\end{array}$ & $\begin{array}{l}-0.581^{* *} \\
(0.267)\end{array}$ & $\begin{array}{l}-0.806^{* * *} \\
(0.247)\end{array}$ & $\begin{array}{c}-1.011^{* * *} \\
(0.214)\end{array}$ & $\begin{array}{c}-0.893^{* * *} \\
(0.249)\end{array}$ & $\begin{array}{c}-0.976^{* * *} \\
(0.189)\end{array}$ & $\begin{array}{l}-0.944^{* * *} \\
(0.226)\end{array}$ & $\begin{array}{c}-0.910^{* * *} \\
(0.204)\end{array}$ \\
\hline $\begin{array}{l}\text { Standard paid } \\
\text { employed } \times(\mathrm{q} / 100)\end{array}$ & $\begin{array}{l}-0.530^{* * *} \\
(0.038)\end{array}$ & $\begin{array}{l}-0.574^{* * *} \\
(0.040)\end{array}$ & $\begin{array}{c}-0.547^{* * *} \\
(0.038)\end{array}$ & $\begin{array}{c}-0.579^{* * *} \\
(0.050)\end{array}$ & $\begin{array}{l}-0.476^{* * *} \\
(0.057)\end{array}$ & $\begin{array}{l}-0.500^{* * *} \\
(0.042)\end{array}$ & $\begin{array}{c}-0.507^{* * *} \\
(0.041)\end{array}$ & $\begin{array}{c}-0.522^{* * *} \\
(0.038)\end{array}$ & $\begin{array}{c}-0.526^{* * *} \\
(0.038)\end{array}$ & $\begin{array}{c}-0.521^{* * *} \\
(0.038)\end{array}$ & $\begin{array}{c}-0.529^{* * *} \\
(0.038)\end{array}$ \\
\hline $\begin{array}{l}\text { Non-standard paid } \\
\text { employed } \times(\mathrm{q} / 100)\end{array}$ & $\begin{array}{l}-0.259^{* *} \\
(0.112)\end{array}$ & $\begin{array}{l}-0.340^{* *} \\
(0.132)\end{array}$ & $\begin{array}{l}-0.253^{* *} \\
(0.115)\end{array}$ & $\begin{array}{l}-0.438^{*} \\
(0.264)\end{array}$ & $\begin{array}{l}-0.213^{*} \\
(0.124)\end{array}$ & $\begin{array}{l}-0.191 \\
(0.122)\end{array}$ & $\begin{array}{l}-0.185 \\
(0.121)\end{array}$ & $\begin{array}{l}-0.270^{* *} \\
(0.112)\end{array}$ & $\begin{array}{l}-0.260^{* *} \\
(0.112)\end{array}$ & $\begin{array}{l}-0.262^{* *} \\
(0.112)\end{array}$ & $\begin{array}{l}-0.266^{* *} \\
(0.112)\end{array}$ \\
\hline $\mathrm{Age}^{2}$ & $\begin{array}{l}0.000^{* *} \\
(0.000)\end{array}$ & $\begin{array}{c}0.000 \\
(0.000)\end{array}$ & $\begin{array}{l}0.000^{*} \\
(0.000)\end{array}$ & $\begin{array}{l}0.000^{* *} \\
(0.000)\end{array}$ & $\begin{array}{c}0.000 \\
(0.000)\end{array}$ & $\begin{array}{c}0.000 \\
(0.000)\end{array}$ & $\begin{array}{c}0.000 \\
(0.000)\end{array}$ & $\begin{array}{c}0.000 \\
(0.000)\end{array}$ & $\begin{array}{l}0.000^{*} \\
(0.000)\end{array}$ & $\begin{array}{c}0.000 \\
(0.000)\end{array}$ & $\begin{array}{l}0.000^{*} \\
(0.000)\end{array}$ \\
\hline Divorced & $\begin{array}{c}0.043 \\
(0.058)\end{array}$ & $\begin{array}{c}0.046 \\
(0.059)\end{array}$ & $\begin{array}{c}0.016 \\
(0.059)\end{array}$ & $\begin{array}{c}0.065 \\
(0.078)\end{array}$ & $\begin{array}{c}0.026 \\
(0.085)\end{array}$ & $\begin{array}{c}0.034 \\
(0.066)\end{array}$ & $\begin{array}{c}0.026 \\
(0.067)\end{array}$ & $\begin{array}{c}0.049 \\
(0.061)\end{array}$ & $\begin{array}{c}0.052 \\
(0.058)\end{array}$ & $\begin{array}{c}0.044 \\
(0.059)\end{array}$ & $\begin{array}{c}0.043 \\
(0.059)\end{array}$ \\
\hline Separated & $\begin{array}{l}-0.283^{* * *} \\
(0.070)\end{array}$ & $\begin{array}{c}-0.290_{* * * *} \\
(0.071)\end{array}$ & $\begin{array}{l}-0.291^{* * *} \\
(0.073)\end{array}$ & $\begin{array}{l}-0.441^{* * *} \\
(0.097)\end{array}$ & $\begin{array}{l}-0.112 \\
(0.100)\end{array}$ & $\begin{array}{c}-0.248^{* * *} \\
(0.078)\end{array}$ & $\begin{array}{l}-0.270^{* * *} \\
(0.079)\end{array}$ & $\begin{array}{l}-0.244^{* * *} \\
(0.073)\end{array}$ & $\begin{array}{c}-0.257^{* * *} \\
(0.071)\end{array}$ & $\begin{array}{l}-0.246^{* * *} \\
(0.071)\end{array}$ & $\begin{array}{c}-0.277^{* * *} \\
(0.073)\end{array}$ \\
\hline Widowed & $\begin{array}{l}-0.611^{* * *} \\
(0.207)\end{array}$ & $\begin{array}{l}-0.726^{* * *} \\
(0.235)\end{array}$ & $\begin{array}{l}-0.672^{* * *} \\
(0.220)\end{array}$ & $\begin{array}{l}-0.485^{* *} \\
(0.247)\end{array}$ & $\begin{array}{l}-0.666^{* *} \\
(0.282)\end{array}$ & $\begin{array}{l}-0.513^{* *} \\
(0.244)\end{array}$ & $\begin{array}{l}-0.629^{* *} \\
(0.268)\end{array}$ & $\begin{array}{l}-0.511^{* *} \\
(0.209)\end{array}$ & $\begin{array}{c}-0.635^{* * *} \\
(0.213)\end{array}$ & $\begin{array}{l}-0.495^{* *} \\
(0.207)\end{array}$ & $\begin{array}{l}-0.641^{* * *} \\
(0.212)\end{array}$ \\
\hline Unwed & $\begin{array}{l}-0.095^{* *} \\
(0.043)\end{array}$ & $\begin{array}{l}-0.098^{* *} \\
(0.047)\end{array}$ & $\begin{array}{l}-0.096^{* *} \\
(0.046)\end{array}$ & $\begin{array}{l}-0.057 \\
(0.058)\end{array}$ & $\begin{array}{l}-0.143^{* *} \\
(0.067)\end{array}$ & $\begin{array}{l}-0.040 \\
(0.051)\end{array}$ & $\begin{array}{l}-0.053 \\
(0.051)\end{array}$ & $\begin{array}{l}-0.082^{*} \\
(0.046)\end{array}$ & $\begin{array}{l}-0.086^{*} \\
(0.045)\end{array}$ & $\begin{array}{l}-0.084^{*} \\
(0.045)\end{array}$ & $\begin{array}{l}-0.083^{*} \\
(0.045)\end{array}$ \\
\hline Children in household & $\begin{array}{c}0.035 \\
(0.024)\end{array}$ & $\begin{array}{c}0.036 \\
(0.025)\end{array}$ & $\begin{array}{c}0.032 \\
(0.025)\end{array}$ & $\begin{array}{l}0.075^{* *} \\
(0.032)\end{array}$ & $\begin{array}{l}-0.026 \\
(0.037)\end{array}$ & $\begin{array}{c}0.010 \\
(0.027)\end{array}$ & $\begin{array}{c}0.021 \\
(0.028)\end{array}$ & $\begin{array}{c}0.039 \\
(0.025)\end{array}$ & $\begin{array}{c}0.033 \\
(0.024)\end{array}$ & $\begin{array}{c}0.035 \\
(0.025)\end{array}$ & $\begin{array}{c}0.033 \\
(0.025)\end{array}$ \\
\hline Recent stays in hospital & $\begin{array}{l}-0.138^{* * *} \\
(0.025)\end{array}$ & $\begin{array}{l}-0.138^{* * *} \\
(0.027)\end{array}$ & $\begin{array}{l}-0.124^{* * *} \\
(0.027)\end{array}$ & $\begin{array}{l}-0.176^{* * *} \\
(0.035)\end{array}$ & $\begin{array}{c}-0.098^{* * *} \\
(0.036)\end{array}$ & $\begin{array}{c}-0.140^{* * * *} \\
(0.027)\end{array}$ & $\begin{array}{l}-0.133^{* * *} \\
(0.027)\end{array}$ & $\begin{array}{c}-0.131^{* * *} \\
(0.026)\end{array}$ & $\begin{array}{c}-0.136^{* * *} \\
(0.026)\end{array}$ & $\begin{array}{c}-0.138^{* * *} \\
(0.026)\end{array}$ & $\begin{array}{c}-0.135^{* * *} \\
(0.026)\end{array}$ \\
\hline Disability: yes & $\begin{array}{c}-0.328^{* * *} \\
(0.059)\end{array}$ & $\begin{array}{c}-0.341^{* * * *} \\
(0.062)\end{array}$ & $\begin{array}{c}-0.330^{* * *} \\
(0.063)\end{array}$ & $\begin{array}{c}-0.368^{* * *} \\
(0.080)\end{array}$ & $\begin{array}{c}-0.278^{* * *} \\
(0.086)\end{array}$ & $\begin{array}{c}-0.318^{* * *} \\
(0.065)\end{array}$ & $\begin{array}{c}-0.319^{* * * *} \\
(0.066)\end{array}$ & $\begin{array}{c}-0.315^{* * *} \\
(0.060)\end{array}$ & $\begin{array}{c}-0.322^{* * *} \\
(0.060)\end{array}$ & $\begin{array}{c}-0.317^{* * *} \\
(0.060)\end{array}$ & $\begin{array}{c}-0.314^{* * *} \\
(0.060)\end{array}$ \\
\hline $\begin{array}{l}\text { Years of unemployment } \\
\text { experience }\end{array}$ & $\begin{array}{c}-0.004 \\
(0.026)\end{array}$ & $\begin{array}{c}0.004 \\
(0.028)\end{array}$ & $\begin{array}{l}-0.006 \\
(0.026)\end{array}$ & $\begin{array}{l}-0.063^{*} \\
(0.034)\end{array}$ & $\begin{array}{c}0.057 \\
(0.039)\end{array}$ & $\begin{array}{c}0.015 \\
(0.031)\end{array}$ & $\begin{array}{c}0.018 \\
(0.030)\end{array}$ & $\begin{array}{l}-0.007 \\
(0.027)\end{array}$ & $\begin{array}{l}-0.004 \\
(0.026)\end{array}$ & $\begin{array}{l}-0.007 \\
(0.027)\end{array}$ & $\begin{array}{l}-0.003 \\
(0.026)\end{array}$ \\
\hline New job & $\begin{array}{c}0.024 \\
(0.022)\end{array}$ & $\begin{array}{c}0.015 \\
(0.024)\end{array}$ & $\begin{array}{c}0.029 \\
(0.023)\end{array}$ & $\begin{array}{l}-0.053^{*} \\
(0.031)\end{array}$ & $\begin{array}{l}0.100^{* * *} \\
(0.032)\end{array}$ & $\begin{array}{c}0.034 \\
(0.025)\end{array}$ & $\begin{array}{c}0.027 \\
(0.025)\end{array}$ & $\begin{array}{c}0.023 \\
(0.023)\end{array}$ & $\begin{array}{c}0.023 \\
(0.023)\end{array}$ & $\begin{array}{c}0.022 \\
(0.023)\end{array}$ & $\begin{array}{c}0.023 \\
(0.023)\end{array}$ \\
\hline Tenure & $\begin{array}{l}-0.005 \\
(0.004)\end{array}$ & $\begin{array}{l}-0.007 \\
(0.005)\end{array}$ & $\begin{array}{l}-0.006 \\
(0.005)\end{array}$ & $\begin{array}{l}-0.006 \\
(0.006)\end{array}$ & $\begin{array}{l}-0.007 \\
(0.007)\end{array}$ & $\begin{array}{l}-0.004 \\
(0.005)\end{array}$ & $\begin{array}{l}-0.004 \\
(0.005)\end{array}$ & $\begin{array}{l}-0.007 \\
(0.005)\end{array}$ & $\begin{array}{l}-0.005 \\
(0.004)\end{array}$ & $\begin{array}{l}-0.006 \\
(0.005)\end{array}$ & $\begin{array}{l}-0.005 \\
(0.004)\end{array}$ \\
\hline Tenure $^{2}$ & $\begin{array}{c}0.000 \\
(0.000)\end{array}$ & $\begin{array}{c}0.000 \\
(0.000)\end{array}$ & $\begin{array}{c}0.000 \\
(0.000)\end{array}$ & $\begin{array}{c}0.000 \\
(0.000)\end{array}$ & $\begin{array}{c}0.000 \\
(0.000)\end{array}$ & $\begin{array}{c}0.000 \\
(0.000)\end{array}$ & $\begin{array}{c}0.000 \\
(0.000)\end{array}$ & $\begin{array}{c}0.000 \\
(0.000)\end{array}$ & $\begin{array}{c}0.000 \\
(0.000)\end{array}$ & $\begin{array}{c}0.000 \\
(0.000)\end{array}$ & $\begin{array}{c}0.000 \\
(0.000)\end{array}$ \\
\hline $\begin{array}{l}\text { Daily working hours, } \\
\text { difference to } 8\end{array}$ & $\begin{array}{l}-0.009^{*} \\
(0.005)\end{array}$ & $\begin{array}{l}-0.011^{*} \\
(0.005)\end{array}$ & $\begin{array}{l}-0.009 * \\
(0.005)\end{array}$ & $\begin{array}{l}-0.017^{* *} \\
(0.008)\end{array}$ & $\begin{array}{l}-0.002 \\
(0.007)\end{array}$ & $\begin{array}{l}-0.012^{* *} \\
(0.006)\end{array}$ & $\begin{array}{l}-0.009 \\
(0.006)\end{array}$ & $\begin{array}{l}-0.008 \\
(0.005)\end{array}$ & $\begin{array}{l}-0.008 \\
(0.005)\end{array}$ & $\begin{array}{l}-0.008 \\
(0.005)\end{array}$ & $\begin{array}{l}-0.009 \\
(0.005)\end{array}$ \\
\hline $\begin{array}{l}\text { Log. equivalence } \\
\text { income, } 2006 \text { prices }\end{array}$ & $\begin{array}{l}0.341^{* * *} \\
(0.030)\end{array}$ & $\begin{array}{l}0.359^{* * *} \\
(0.032)\end{array}$ & $\begin{array}{l}0.350^{* * *} \\
(0.031)\end{array}$ & $\begin{array}{l}0.360^{* * *} \\
(0.040)\end{array}$ & $\begin{array}{l}0.337^{* * *} \\
(0.046)\end{array}$ & $\begin{array}{l}0.309^{* * *} \\
(0.035)\end{array}$ & $\begin{array}{l}0.313^{* * *} \\
(0.035)\end{array}$ & $\begin{array}{l}0.309^{* * *} \\
(0.032)\end{array}$ & $\begin{array}{l}0.334^{* * *} \\
(0.031)\end{array}$ & $\begin{array}{l}0.320^{* * *} \\
(0.031)\end{array}$ & $\begin{array}{l}0.330^{* * *} \\
(0.031)\end{array}$ \\
\hline Home ownership & $\begin{array}{l}0.074^{* *} \\
(0.029)\end{array}$ & $\begin{array}{l}0.088^{* * *} \\
(0.030)\end{array}$ & $\begin{array}{l}0.061^{* *} \\
(0.030)\end{array}$ & $\begin{array}{l}0.103^{* * *} \\
(0.037)\end{array}$ & $\begin{array}{c}0.033 \\
(0.045)\end{array}$ & $\begin{array}{l}0.099^{* * *} \\
(0.033)\end{array}$ & $\begin{array}{l}0.114^{* * *} \\
(0.033)\end{array}$ & $\begin{array}{l}0.092^{* * *} \\
(0.029)\end{array}$ & $\begin{array}{c}0.080^{* * *} \\
(0.029)\end{array}$ & $\begin{array}{c}0.087^{* * *} \\
(0.029)\end{array}$ & $\begin{array}{l}0.081^{* * *} \\
(0.030)\end{array}$ \\
\hline Time fixed effects & yes & yes & yes & yes & yes & yes & yes & yes & yes & yes & yes \\
\hline Individual fixed effects & yes & yes & yes & yes & yes & yes & yes & yes & yes & yes & yes \\
\hline Constant & $\begin{array}{l}3.995^{* * *} \\
(0.369)\end{array}$ & $\begin{array}{l}4.145^{* * *} \\
(0.426)\end{array}$ & $\begin{array}{l}3.975^{* * *} \\
(0.381)\end{array}$ & $\begin{array}{c}3.483^{* * *} \\
(0.497)\end{array}$ & $\begin{array}{c}4.496^{* * *} \\
(0.553)\end{array}$ & $\begin{array}{l}4.546^{* * *} \\
(0.429)\end{array}$ & $\begin{array}{c}4.509^{* * *} \\
(0.430)\end{array}$ & $\begin{array}{l}4.366^{* * *} \\
(0.385)\end{array}$ & $\begin{array}{c}4.055^{* * *} \\
(0.377)\end{array}$ & $\begin{array}{c}4.273^{* * *} \\
(0.380)\end{array}$ & $\begin{array}{c}4.097^{* * *} \\
(0.379)\end{array}$ \\
\hline Observations & 56,397 & 51,589 & 51,821 & 30,507 & 25,860 & 47,188 & 47,516 & 52,986 & 54,702 & 53,766 & 54,229 \\
\hline Number of persons & 19,436 & 17,746 & 18,056 & 10,200 & 9,236 & 17,646 & 17,689 & 18,564 & 19,014 & 18,751 & 18,901 \\
\hline Adjusted $\mathrm{R}^{2}$ & 0.038 & 0.041 & 0.039 & 0.046 & 0.034 & 0.035 & 0.033 & 0.036 & 0.038 & 0.036 & 0.038 \\
\hline
\end{tabular}

Source: SOEP 1999 (except [5] and [6]), 2001, 2003, 2005, 2007, 2009.

Note: ${ }^{*} p<0.1,{ }^{* *} p<0.0{ }^{* * * *} p<0.01$. Robust standard errors in parentheses. The table displays subgroup analyses using the methodology of the first estimation approach (Specification I-4). The dependent variable is life satisfaction. The first column displays the results obtained from the whole sample. In contrast, the subsamples include (2) no workers younger than 25 or older than 60 years, (3) no civil servants, (4) men only, (5) women only, self-employed workers only who (6) employ others, (7) do not employ others, (8) are freelancers with an academic degree, (9) are other business owners, (10) provide services, (11) do not provide services. The hypothetical reference group is standard paid employed, reports $0 \%$ probability of losing work, is 0 years old, married, not living with children in the same household, not disabled, did not stay overnight in hospital during the previous 12 months, experienced 0 years of unemployment so far, is longer paid employed or self-employed than since the previous interview, reports 0 years of tenure, works 8 hours a day, was interviewed in 2009, receives no equivalence income and does not own its home. 


\section{References}

Andersson, Pernilla (2008): "Happiness and health: well-being among the self-employed", Journal of Socio-Economics, 37, pp. 213-236.

Benz, Matthias and Bruno S. Frey (2008a): "Being independent is a great thing: subjective evaluations of self-employment and hierarchy”, Economica, 75, pp. 362-383.

Benz, Matthias and Bruno S. Frey (2008b): "The value of doing what you like: evidence from the self-employed in 23 countries", Journal of Economic Behavior and Organization, 68, pp. 445-455.

Binder, Martin and Alex Coad (2013): "Life satisfaction and self-employment: a matching approach”, Small Business Economics, 40, pp. 1009-1033.

Blanchflower, David G. (2000): "Self-employment in OECD countries", Labour Economics, 7, pp. 471-505.

Blanchflower, David G. and Andrew J. Oswald (2004): "Well-being over time in Britain and the USA", Journal of Public Economics, 88, pp. 1359-1386.

Block, Joern and Philipp Koellinger (2009): "I can't get no satisfaction - necessity entrepreneurship and procedural utility", Kyklos, 62, pp. 191-209.

Bonsang, Eric and Tobias J. Klein (2012): "Retirement and subjective well-being", Journal of Economic Behavior and Organization, 83, pp. 311-329.

Caliendo, Marco, Frank M. Fossen and Alexander S. Kritikos (2009): "Risk attitudes of nascent entrepreneurs - new evidence from an experimentally validated survey", Small Business Economics, 32, pp. 153-167.

Caliendo, Marco, Frank M. Fossen and Alexander S. Kritikos (2014): "Personality characteristics and the decisions to become and stay self-employed", Small Business Economics, 42, pp. 787-814.

Chadi, Adrian (2010): "How to distinguish voluntary from involuntary unemployment: on the relationship between the willingness to work and unemployment-induced unhappiness", Kyklos, 63, pp. 317-329.

Chadi, Adrian (2012): "Employed but still unhappy? On the relevance of the social work norm", Schmollers Jahrbuch, 132, pp. 1-26.

Chadi, Adrian and Clemens Hetschko (2013): Flexibilisation without hesitation? Temporary contracts and workers' satisfaction, Freie Universität Berlin, School of Business and Economics Discussion Paper, 3/2013.

Chadi, Adrian and Clemens Hetschko (2014): The magic of the new: how job changes affect job satisfaction, IAAEU Discussion Paper, 5/2014.

Clark, Andrew E. and Andrew J. Oswald (1994): "Unhappiness and unemployment", Economic Journal, 104, pp. 648-659. 
Clark, Andrew E., Yannis Georgellis and Peter Sanfey (2001): "Scarring: the psychological impact of past unemployment", Economica, 68, pp. 221-241.

Clark, Andrew E. (2003): "Unemployment as a social norm: psychological evidence from panel data", Journal of Labor Economics, 21, pp. 323-351.

Clark, Andrew E., Ed Diener, Yannis Georgellis and Richard E. Lucas (2008a): "Lags and leads in life satisfaction: a test of the baseline hypothesis", Economic Journal, 118, pp. F222-F243.

Clark, Andrew E., Nathalie Colombier and David Masclet (2008b): "Never the same after the first time: the satisfaction of the second-generation self-employed", International Journal of Manpower, 29, pp. 591-609.

Clark, Andrew E., Andreas Knabe and Steffen Rätzel (2010): "Boon or bane? Others' unemployment, well-being and job security”, Labour Economics, 17, pp. 52-61.

Di Tella, Rafael, Robert J. MacCulloch and Andrew J. Oswald (2001): "Preferences over inflation and unemployment: evidence from surveys of happiness", American Economic Review, 91, pp. 335-341.

Dickerson, Andy and Francis Green (2012): "Fears and realisations of employment insecurity”, Labour Economics, 19, pp. 198-210.

European Commission (2010): Self-employment in Europe 2010, Luxembourg: European Union.

Fuchs-Schündeln, Nicola (2009): "On preferences for being self-employed”, Journal of Economic Behavior and Organization, 71, pp. 162-171.

Geishecker, Ingo (2012): "Simultaneity bias in the analysis of perceived job insecurity and subjective well-being”, Economics Letters, 116, pp. 319-321.

Gerlach, Knut and Gesine Stephan (1996): “A paper on unhappiness and unemployment in Germany”, Economics Letters, 52, pp. 325-330.

Gielen, Anne C. and Jan van Ours (2014): "Unhappiness and Job Finding”, Economica, 81, pp. 544-565.

Green, Francis (2011): "Unpacking the misery multiplier: how employability modifies the impacts of unemployment and job insecurity on life satisfaction and mental health", Journal of Health Economics, 30, pp. 265-276.

Hamilton, Barton H. (2000): "Does entrepreneurship pay? An empirical analysis of returns to self-employment”, Journal of Political Economy, 108, pp. 604-631.

Hetschko, Clemens, Andreas Knabe and Ronnie Schöb (2014): "Changing identity: retiring from unemployment”, Economic Journal, 124, pp. 149-166.

Hundley, Greg (2001): "Why and when are the self-employed more satisfied with their work?", Industrial Relations, 40, pp. 293-316. 
Hytti, Ulla, Teemu Kautonen and Elisa Akola (2013): "Determinants of job satisfaction for salaried and self-employed professionals in Finland", International Journal of Human Resource Management, 24, pp. 2034-2053.

Kassenboehmer, Sonja C. and John P. Haisken De-New (2009): "You're fired! The causal negative effect of entry unemployment on life satisfaction", Economic Journal, 119, pp. $448-462$.

Knabe, Andreas, Stefen Rätzel, Ronnie Schöb and Joachim Weimann (2010): "Dissatisfied with life but having a good day: time-use and well-being of the unemployed", Economic Journal, 120, pp. 867-889.

Knabe, Andreas and Steffen Rätzel (2010): "Better an insecure job than no job at all? Unemployment, job insecurity and subjective well-being", Economics Bulletin, 30, pp. 2486-2494.

Knabe, Andreas and Steffen Rätzel (2011): "Scarring or scaring? The psychological impact of past unemployment and future unemployment risk", Economica, 78, pp. 283-293.

Krause, Annabelle (2013): "Don't worry, be happy? Happiness and reemployment”, Journal of Economic Behavior and Organization, 96, pp. 1-20.

Krueger, Alan B. and Andreas I. Mueller (2012): "Time use, emotional well-being, and unemployment: evidence from longitudinal data", American Economic Review, 102, pp. 594-599.

Lange, Thomas (2012): “Job satisfaction and self-employment: autonomy or personality?", Small Business Economics, 38, pp. 165-177.

Luechinger, Simon, Stephan Meier and Alois Stutzer (2010): "Why does unemployment hurt the employed? Evidence from the life satisfaction gap between the public and the private sector”, Journal of the European Economics Association, 45, pp. 998-1045.

Millàn, José Maria, Jolanda Hessels, Roy Thurik and Rafael Aguado (2013): "Determinants of job satisfaction: a European comparison of self-employed and paid employees", Small Business Economics, 40, pp. 651-670.

Parasuraman, Saroj and Claire A. Simmers (2001): "Type of employment, work-family conflict and well-being: a comparative study", Journal of Organizational Behavior, 22, pp. 551-568.

Parker, Simon C. (2009): The economics of entrepreneurship, Cambridge: Cambridge University Press.

Schulze Buschoff, Karin (2007): Neue Selbstständige im Vergleich, Düsseldorf: HansBöckler-Stiftung.

Shane, Scott (2008): Illusions of entrepreneurship: the costly myths that entrepreneurs, investors, and policy makers live by, New Haven: Yale University Press.

Stutzer, Alois and Rafael Lalive (2004): "The role of social work norms in job searching and subjective well-being", Journal of the European Economic Association, 2, pp. 696-719. 
Torres, Olivier (2011): "The silent and shameful suffering of bosses: layoffs in SME", International Journal of Entrepreneurship and Small Business, 13, pp. 181-192.

Van Hoorn, André and Robert Maseland (2013): "Does a protestant work ethic exist? Evidence from the well-being effect of unemployment", Journal of Economic Behavior \& Organization, 91, pp. 1-12.

Wagner, Gert G., Joachim R. Frick and Jürgen Schupp (2007): "The German Socio-Economic Panel study (SOEP) - scope, evolution and enhancements", Schmollers Jahrbuch, 127, pp. 139-170.

Weimann, Joachim, Andreas Knabe and Ronnie Schöb (in press): Measuring happiness: the economics of well-being, Cambridge: MIT press.

Winkelmann, Liliana and Rainer Winkelmann (1998): "Why are the unemployed so unhappy? Evidence from panel data", Economica, 65, pp. 1-15.

Winkelmann, Rainer (2009): "Unemployment, social capital, and subjective well-being", Journal of Happiness Studies, 10, pp. 421-430. 